\title{
The Sustainability of Fiscal Policy IN THE UNITED STATES
}

\author{
HENNING BOHN \\ CESIFO WORKING PAPER NO. 1446 \\ CATEGORY 1: PUBLIC FINANCE \\ APRIL 2005
}

An electronic version of the paper may be downloaded

- from the SSRN website:

www.SSRN.com

- from the CESifo website:

www.CESifo.de 


\title{
THE SUSTAINABILITY OF FisCAL POLICY IN THE UNITED STATES
}

\begin{abstract}
The paper examines the sustainability of U.S. fiscal policy, finding substantial evidence in favor. I summarize the U.S. fiscal record from 1792-2003, critically review sustainability conditions and their testable implications, and apply them to U.S. data. I particularly emphasize the ramifications of economic growth. A "growth dividend" has historically covered the entire interest bill on the U.S. debt. Unit root tests on real series, unscaled by GDP, are distorted by the series' severe heteroskedasticity. The most credible evidence in favor of sustainability is the robust positive response of primary surpluses to fluctuations in the debt-GDP ratio.
\end{abstract}

JEL Code: H6, H0, E6.

Keywords: public debt, sustainability, primary surplus, unit root.

\author{
Henning Bohn \\ Department of Economics \\ University of California Santa Barbara \\ Santa Barbara \\ CA 93106 \\ USA \\ bohn@econ.ucsb.edu
}

The paper was presented at the CESifo/LBI Conference on the Sustainability of Public Debt in Oct.2004. I would like to thank Reinhard Neck, Alfred Greiner, and the other conference participants for helpful comments and suggestions. 


\section{Introduction}

The U.S. fiscal balance has shown tremendous variation in recent years. Large budget deficits in the 1980s and early 1990s triggered a substantial literature examining the sustainability of U.S. budget deficits. Concerns about U.S. budget deficits evaporated in the late 1990s, as deficits turned into record surpluses, leaving a stack of unreconciled theoretical and empirical findings. As the U.S. fiscal balance has turned sharply negative since 2001, the sustainability of U.S. fiscal policy is again a pressing issue.

This paper critically reviews the conceptual issues and presents new evidence, drawing on the historical record of U.S. fiscal policy from 1792-2003. Section 2 lays out a framework and summarizes U.S. data, emphasizing the role of economic growth. Sections 3-4 examine commonly used “ad hoc” versions of the government's intertemporal budget constraint (IBC) and test the implied stationarity restrictions. Sections 5-6 derive the IBC in a general equilibrium setting and examine its theoretical and empirical implications. U.S. primary surpluses are found to respond positively to fluctuations in public debt. This response satisfies a sufficient condition for sustainability. Section 7 briefly comments on seignorage, on the fiscal theory of the price level, and on social security. Section 8 concludes.

\section{U.S. Fiscal Data and Economic Growth}

Starting point for analyzing government budgets is the budget identity linking the deficit to revenues, spending, and public debt. The deficit is the difference between outlays and revenues. It also equals the change in public debt. In algebraic terms, let $\mathrm{DEF}_{\mathrm{t}}$ denote the with-interest deficit in year $\mathrm{t}, \mathrm{T}_{\mathrm{t}}$ total revenues, $G_{t}$ non-interest spending, $D_{t-1}$ the public debt at the end of year $t-1$ (all in nominal dollars), and $i_{t}$ the interest charge. The budget identities are then

$$
D E F_{t}=G_{t}-T_{t}+i_{t} \cdot D_{t-1}
$$

and

$$
D_{t}=D_{t-1}+D E F_{t}
$$


Most policy debates about the U.S. budget deficit focus on the nominal with-interest deficit ("headline deficit”), and on the resulting buildup of Public Debt. ${ }^{1}$ Data for revenues and outlays are commonly taken from the Unified Budget, which includes social security and other trust fund accounts as well as Federal Reserve transfers to the Treasury.

Figure 1 displays the headline deficit for 1900-2003 and Congressional Budget Office (CBO) projections (dotted) for 2004-2014. Visible as downward spike are the surpluses of the late 1990s, bracketed by large deficits in the 1980s and in the post-2001 period. Pre-1970 deficits are barely visible in nominal dollar terms, apart from WWII. Post-1970, the U.S. government has run budget deficits every year, except for 1998-2001. In Figure 1, the 1990s surpluses look like outliers in a longer-run trend towards rising deficits. CBO projects substantial deficits into the indefinite future. ${ }^{2}$

Figure 2 displays U.S. public debt in nominal and real terms for 1900-2003. The run-up in nominal debt reflects the deficits shown in Fig.1, highlighting the rapid debt-growth since 1980 and the "pause" in debt growth in the 1990s. Adjusting for inflation magnifies historical debt values relative to recent ones. In the real series, debts from WWI become noticeable, but pre-1916 values look negligible relative to current debt. The real series shows that debt growth from 1950-80 was entirely nominal, whereas the post-1980 debt growth was real.

Figure 3 displays the ratio of U.S. public debt to the size of the economy (GDP) for 17912003. Scaling debt by the size of the economy further shrinks recent debt values relative to earlier ones, enough that it becomes instructive to display the entire history of U.S. debt. The debt-GDP ratio suggests a more benign view of U.S. fiscal policy than the nominal and real series. The 36\% debt-GDP ratio in 2003 is comparable to the starting value in 1791 (about 40\%). With the exception of WWII, the U.S. time series lies below $60 \%$, the value European politicians seem to view as hallmark of a responsible fiscal policy.

\footnotetext{
${ }^{1}$ I follow the sustainability literature and disregard the U.S. government's ownership of real and financial assets; this is in effect asking if U.S. policy is sustainable without asset sales. Otherwise, (2a) would have to be modified to equate the deficit to the change in government liabilities minus the change in assets. Treasury cash balances should also be deducted from Public Debt, but they are small enough to be ignored.

2 CBO provides "baseline” projections and several alternatives. The baseline abide by politically mandated assumptions and must be interpreted with caution. To avoid the baseline assumption, the projections in Figure 1 show CBO projections of President Bush's budget (as of March 2004).
} 
Figure 3 also highlights the central role of wars in the build-up of debt. Five major wars- the War of Independence, Spanish-American War, the Civil War, World War I and World War II-were largely deficit-financed. This explains the high debt-GDP ratio in 1791 and the sharp increases in 1812-16, 1861-66, 1916-19, and 1941-46. The debt-GDP ratio has generally declined during peacetime periods, with the exception of the Great Depression/New Deal era (1929-39), the 1980s, and the post-2001 period. One might even interpret the 1980s as hot phase of the Cold War and the post2001 period as the War on Terror, which would leave the Great Depression as the sole episode of peacetime increases in the debt/GDP ratio.

While Fig.2-3 refer to U.S. Public Debt, press reports about U.S. debts sometimes refer to a different concept, Gross Federal Debt. The latter includes intra-governmental obligations to social security and other trust funds, and it far exceeds the public debt (\$6700bill. vs. \$3914bill. as of Sept.2003). Eq. (2a) does not apply to Gross Debt unless one uses a different, much narrower deficit concept that excludes social security and other trust funds. My analysis follows the Unified budget (except Section 7 below), in effect disregarding intra-governmental flows.

Figure 4 displays the deficit-GDP ratio, the ratio of nominal headline deficits over GDP. The deficit-GDP ratio illustrates the extraordinary magnitude of wartime deficits, the persistently high deficits in the post-1980 period, and the late-1990s surpluses. Note that peacetime budget surpluses are not nearly as large as the wartime deficits, neither year-by-year nor as integral over time.

The contrast between the positive deficits in Fig. 4 and the flat path of debt in Fig.3 illustrates a key point: The common intuition equating deficits with increases in debt does not apply to real values nor to GDP-ratios. While $D E F=\Delta D$ holds in nominal terms as shown in (2a), changes in real debt differ from the real value of the deficit by an inflation term,

$$
\Delta(D / P)_{t}=\frac{D_{t}}{P_{t}}-\frac{D_{t-1}}{P_{t-1}}=\frac{D E F_{t}}{P_{t}}-\frac{D_{t-1}}{P_{t-1}} \frac{\pi_{t}}{1+\pi_{t}}
$$

where $P_{t}$ is the price level (empirically, the GDP deflator) and $\pi_{t}=P_{t} / P_{t-1}-1$ is the inflation rate. Similarly, changes in the debt-GDP ratio differ from the deficit-GDP ratio by a nominal growth term,

$$
\Delta(D / Y)_{t}=\frac{D_{t}}{Y_{t}}-\frac{D_{t-1}}{Y_{t-1}}=\frac{D E F_{t}}{Y_{t}}-\frac{D_{t-1}}{Y_{t-1}} \frac{\gamma_{t}}{1+\gamma_{t}}
$$


where $Y_{t}$ is nominal GDP and $\gamma_{t}=Y_{t} / Y_{t-1}-1$ is nominal GDP-growth. The nominal growth term-a "growth dividend" - could be decomposed into an inflation term (as in (2b)) plus a real growth effect. I omit the decomposition to highlight that GDP-ratios are ratios of nominal dollar values and hence not subject to controversies about measuring inflation. Because of the inflation and growth effects, the interest charge $i_{t} \cdot D_{t-1}$ in the headline deficit systematically overstates the impact of initial debt on real debt accumulation and on the debt-GDP ratio. This explains the mismatch between Fig. 3 and Fig.4.

The primary deficit, $D E F_{t}^{0}=G_{t}-T_{t}$, is useful in this context, both to separate the stock of debt from the flows of outlays and revenues, and to obtain a scale-invariant exposition of debt dynamics. From (1) and (2a), the nominal budget equation can be written as

$$
D_{t}=G_{t}-T_{t}+\left(1+i_{t}\right) \cdot D_{t-1}=D E F_{t}^{0}+\left(1+i_{t}\right) \cdot D_{t-1} .
$$

The corresponding real and GDP-ratio versions,

$$
\frac{D_{t}}{P_{t}}=\frac{D E F_{t}^{0}}{P_{t}}+\left(\frac{1+i_{t}}{1+\pi_{t}}\right) \cdot \frac{D_{t-1}}{P_{t-1}} \text { and } \frac{D_{t}}{Y_{t}}=\frac{D E F_{t}^{0}}{Y_{t}}+\left(\frac{1+i_{t}}{1+\gamma_{t}}\right) \cdot \frac{D_{t-1}}{Y_{t-1}}
$$

are similar in that they express period-t debt as sum of a flow variable — the primary deficit—and the previous period's debt multiplied by a propagation factor. Let $d_{t}$ denote a generic, scaled version of debt (e.g., $\mathrm{D}_{t}$ or $\mathrm{D}_{t} / \mathrm{P}_{t}$ or $\mathrm{D}_{t} / \mathrm{Y}_{t}$, as needed), let $\mathrm{s}_{t}$ denote the corresponding version of the primary surplus (meaning $-D E F_{t}^{0}$ or $-D E F_{t}^{0} / P_{t}$ or $-D E F_{t}^{0} / Y_{t}$ ), and let $\mathrm{r}_{\mathrm{t}}$ denote the appropriate version of the "return" on debt (meaning, $r_{t}=i_{t} \quad$ or $\quad r_{t}=\left(1+i_{t}\right) /\left(1+\pi_{t}\right)-1 \approx i_{t}-\pi_{t} \quad$ or $\left.r_{t}=\left(1+i_{t}\right) /\left(1+g_{t}\right)-1 \approx i_{t}-\gamma_{t}\right)$. Then the dynamics of public debt can described compactly as

$$
d_{t}=\left(1+r_{t}\right) \cdot d_{t-1}-s_{t}
$$

Eq.(4) demonstrates that budget accounting is scale-invariant if one uses the appropriate propagation factor. Eq.(4) also highlights that alternative tax and spending policies have an impact on debt accumulation only to the extent that they affect $s_{t}$ and $r_{t}$.

Table 1 documents the quantitative importance of economic growth for the dynamics of the U.S. debt. Column 1 shows average with-interest deficits in percent of GDP. Columns 2-4 displays corresponding values for the primary deficit, the nominal interest charge, and the growth dividend 
from (2c), all in percent of GDP. In Col.5-6, growth dividend is decomposed into real growth and the inflation effect from (2b). Column 7 displays the average growth rate of the debt-GDP ratio.

Over the full 1792-2003 sample (top row), the U.S. government has run with-interest deficits averaging about 1.2\% of GDP (col.1). Even excluding interest, the U.S. has run deficits averaging about $0.3 \%$ of GDP (col.2). The debt-GDP ratio, in contrast, has remained essentially constant (col.7), suggesting that $\left(1+i_{t}\right) /\left(1+\gamma_{t}\right)-1$ must have been negative on average. Col.4 confirms that the growth dividend has been enough to cover average interest changes and primary deficits. Economic growth rather than primary surpluses have held down the debt-GDP ratio.

The role of economic growth is robust if one splits the sample. Sub-sample variations arise mainly because inflation rates differ in the pre- and post-Gold Standard periods and because subsamples may include an above or below average number of war years. If one splits the sample in 1914, the 1792-1914 sample shows a lower with-interest deficit, a declining debt-GDP ratio, and a primary surplus, whereas the 1915-2003 sample shows higher with-interest and primary deficits and an increasing debt-GDP ratio. While GDP growth for 1792-1914 was non-inflationary, inflation was a major component of nominal growth for 1915-2003. The increase in the inflation component (from $0.02 \%$ to $1.17 \%$ ) was matched almost one-for-one an increased nominal interest change (from $0.49 \%$ to $1.57 \%$ ). This suggests that the Fisher effect reasonably approximates the long-run data, i.e., the relation between interest charge and growth dividend is not due to unexpected inflation. Similar results are obtained if one splits the sample in $1868 .^{3}$

Table 2 displays average growth rates, inflation rates, and interest rates on the U.S. debt for the same sample periods as in Table 1. Col. 1-4 present essentially the same information as in Col.3-6 in Table 1, but as simple averages rather than averages weighted by debt-GDP ratios (in Table 1). Table 2 confirms that average economic growth has usually exceeded the average interest charge on public debt.

Note that Table 2 does not allow inferences about the dynamic efficiency of the U.S. economy. As shown by Abel et al. (1989), dynamic efficiency depends on the relationship between

\footnotetext{
3 The 1914 split is motivated by WWI and $16^{\text {th }}$ Amendment, the start of income taxation. The 1868 split is motivated by the Civil war.
} 
capital share and investment share in GDP (or approximately, the return on real capital and the growth rate). Abel et al. show that the U.S. capital share has consistently exceeded the investment share, indicating dynamic efficiency. Instead, Tables 1-2 suggest that the U.S. government has exploited the gap between the return on capital and the return on bonds to economize on its debt service.

In summary, for the last $200+$ years the U.S. government has been able to rely on economic growth to keep its debt-GDP ratio from rising. Most of the time, the U.S. has had no need to run primary surpluses, and indeed, it did not run primary surpluses on average. Much of the sustainability literature, in contrast, starts from the premise that primary surpluses are necessary to keep the public debt from growing exponentially.

\section{Ad Hoc Sustainability}

This section will examine the U.S. fiscal record from an applied perspective and review sustainability conditions commonly used in the literature. In principle, sustainability involves two questions. Which fiscal policies are sustainable? And what can we say about the sustainability of particular policies encountered in practice?

Much of the sustainability literature has skipped the first question and focused on the empirical implications of a simple ad hoc definition of sustainability:

Definition [Ad Hoc Sustainability]: A fiscal policy satisfies ad hoc sustainability, if it is on a trajectory such that the expected present value of future primary surpluses equals the initial debt.

This is a flawed definition—as I will demonstrate—but worth examining, in part because it motivates standard empirical tests, in part to highlight the flaws.

From eq. (4), one can readily compute the paths of public debt implied by arbitrary sequences of primary surpluses and of interest charges,

$$
d_{t+n}=\left(\prod_{k=0}^{n}\left(1+r_{t+k}\right)\right) \cdot d_{t-1}-\sum_{j=0}^{n}\left(\prod_{k=j+1}^{n}\left(1+r_{t+k}\right)\right) \cdot s_{t+j}
$$


Conditions for ad-hoc sustainability are obtained from (5) in three steps, all of which are valid in nominal terms, in real terms, and for GDP-ratios. First replace the returns in (5) by a fixed value $r$ and take conditional expectations,

$$
E_{t}\left[d_{t+n}\right]=(1+r)^{n} \cdot d_{t}^{*}-\sum_{j=0}^{n}(1+r)^{n-j} \cdot E_{t}\left[s_{t+j}\right]
$$

where $d_{t}^{*}=\left(1+r_{t}\right) \cdot d_{t-1}$ denotes debt at the start of period $t$ and where $E_{t}[\cdot]$ denotes conditional expectations. Second, divide by $(1+r)^{n}$ and rearrange to obtain

$$
d_{t}^{*}=\sum_{j=0}^{n} \frac{1}{(1+r)^{j}} E_{t}\left[s_{t+j}\right]+\frac{1}{(1+r)^{n}} E_{t}\left[d_{t+n}\right]
$$

Finally, assume the discounted sum converges and take the limit $n \rightarrow \infty$; then

$$
d_{t}^{*}=\sum_{j=0}^{\infty} \frac{1}{(1+r)^{j}} E_{t}\left[s_{t+j}\right]+\lim _{n \rightarrow \infty} \frac{1}{(1+r)^{n}} E_{t}\left[d_{t+n}\right] .
$$

Eq. (7) demonstrates that initial debt equals the expected present value of future primary surpluses if and only if discounted future debt converges to zero. That is,

$$
d_{t}^{*}=\sum_{j=0}^{\infty} \frac{1}{(1+r)^{j}} E_{t}\left[s_{t+j}\right]
$$

is equivalent to

$$
\lim _{n \rightarrow \infty} \frac{1}{(1+r)^{n}} E_{t}\left[d_{t+n}\right]=0
$$

Eq. (8) is commonly known as the Intertemporal Budget Constraint (IBC) and (9) as the Transversality Condition (TC).

The derivation highlights the arbitrariness of the discount rate $r$ and the absence of an economic argument why potential buyers of government bonds should care about (8) or (9). The sustainability literature commonly interprets $\mathrm{r}$ as an expected return on government bonds, proxied by some historical average. Because (7) is an identity for any r, the IBC (8) has economic content only by the assertion that for the particular r-value chosen by the study's author, (9) describes the bondholders' transversality condition. This would make (9) a necessary condition for individuals to hold government bonds and would justify (8) as a true constraint on government policy. 
While early empirical work has attempted to test (9) directly, ${ }^{4}$ most research has focused on testing (8) by examining the unit root and co-integration properties of fiscal data. In an influential paper, Trehan and Walsh (1988) show that if real revenues, real spending, and real debt have unit roots, a stationary with-interest deficit is sufficient for (8-9). Equivalent statements (invoking the budget identity with fixed r) are that the primary surplus and debt are co-integrated with a cointegrating vector (1,-r); or that revenues, non-interest spending, and debt are co-integrated with vector $(1,-1,-r)$. Trehan and Walsh (1991) generalize this result in two directions: With variable discount rates, IBC holds if debt is difference-stationary and if the discount rate is strictly positive and bounded away from zero. Alternatively, covering the case of non-stationary with-interest deficits, IBC holds if debt a quasi-difference $d_{t}-\lambda d_{t-1}$ of debt is stationary for some $0 \leq \lambda<1+r$ and if debt and primary surpluses are cointegrated.

Two simple observations provide an intuition for these unit root and cointegration results. First, it's a math fact that exponential decay dominates polynomial growth. If debt is differencestationary with some finite mean $\delta$, the expected debt n-periods ahead is approximately

$$
E_{t}\left[d_{t+n}\right] \approx \bar{d}_{t}+n \cdot \delta
$$

a linear function of $\mathrm{n}$, where $\bar{d}_{t}$ denotes the permanent component of $d_{t}$ (as defined by Beveridge and Nelson 1981). Because (8) divides this expression by the exponential $(1+r)^{n}$, the dominance of exponential decay over linear growth implies a zero limit for any $r>0 . .^{5}$ This explains Trehan and Walsh's (1988) result and the difference-stationarity result in Trehan-Walsh (1991). Trehan-Walsh’s (1991) cointegration result derives from a second observation: exponential debt growth is consistent with (8) if the growth rate is strictly less than $\mathrm{r}$ (McCallum 1984). If $d_{t}-\lambda d_{t-1}$ is stationary as Trehan-Walsh assume, the asymptotic rate of debt growth is $\lambda-1$, so $\lambda<1+r$ suffices for (8).

\footnotetext{
${ }^{4}$ Hamilton and Flavin (1986) test (9) against the alternative of a "speculative bubble” by regressing a time series of U.S. real debt against an exponential terms of the order $(1+r)$ and examine the significance of the exponential. They find no bubble in U.S. debt for 1960-84. Wilcox (1989) computes realized values of discounted debt, $d_{t+n} / \prod_{k=0}^{n-1}\left(1+r_{t+k}\right)$, for fixed $\mathrm{t}=1960$ and $\mathrm{n}=0 . . .24$, using real U.S. debt for 1960-84 and using the ex-post real returns on such debt. This yields an empirical counterpart to (9) that does not require a fixed interest rate, but it assert that the ex-post real return on debt is the appropriate discount rate; see Bohn (1995) for a critique.

${ }^{5}$ By the same argument, if debt were stationary after differentiating $\mathrm{m}$ times, for any finite $\mathrm{m}$, expected debt would be an $\mathrm{m}$ th order polynomial in $\mathrm{n}$, so (8) is satisfied for any $\mathrm{r}>0$. I am not aware of a formal proof for this intuition.
} 
Trehan-Walsh’s (1991) cointegration result has a noteworthy additional implication. Cointegration between surplus and debt means that some linear combination $s_{t}-\alpha \cdot d_{t-1}=u_{t}$ is stationary, where $\alpha$ is a constant and $u_{t}$ a stationary process. Next period's debt can then be written as $d_{t+1}=(1+r) \cdot d_{t}-s_{t+1}=(1+r-\alpha) \cdot d_{t}+u_{t+1}$, so $\lambda=1+r-\alpha$ and therefore $\alpha=1+r-\lambda>0$. Trehan-Walsh’s (1991) assumptions therefore imply a strictly positive linkage between surplus and $\operatorname{debt}(\alpha>0){ }^{6}$

From an economic perspective, one might wonder about the types of polices that might lead to (8-9) being satisfied or violated. Two polar scenarios are instructive. First, suppose politicians are oblivious to public debt, making exogenous decisions about taxes and about non-interest spending. Then (8-9) are only satisfied by accident, only if the stochastic processes describing taxes and spending decisions happen to have the property that deficit-increasing shocks in one period are exactly offset in present value terms by deficit-decreasing shocks in subsequent periods (see Hansen et al 1991). Secondly, suppose politicians are instead responsive to public debt. They are more cautious about tax cuts and about spending growth whenever the debt has increased, and more willing to cut taxes and to increase spending when the debt has decreased. Such responses to debt would implement an error-correction mechanism that might stabilize the debt or at least generate cointegration between debts and primary surpluses. The empirical question about sustainability is which of these scenarios better characterizes a country’s political process.

A disturbing feature of ad hoc sustainability is the apparent disconnect from practical politics. While political debates about sustainability are mostly about bounds on debt-GDP and/or deficit-GDP ratios, much of the academic literature has focused on real fiscal series and treats non-stationary debtGDP ratios as unproblematic.

\section{Empirical Analysis: Unit Roots versus Stationarity}

This section critically examines the time series properties of U.S. fiscal variables, focusing on unit root tests for ad hoc sustainability. Cointegration is not examined, to save space and because the

\footnotetext{
6 To anticipate, this linkage is consistent with policy reaction function examined below. Wickens and Uctum (1993) have derived similar linkages between external debt and the current account.
} 
stationarity of a deficit measure and the cointegration of its non-stationary components are conceptually equivalent. ${ }^{7}$

Table 3 presents unit tests for real variables - for public debt, the with-interest deficit, the primary deficit, revenues, non-interest outlays, and a decomposition of non-interest outlays into military and non-military ones. The Phillips-Perron (PP) and augmented Dickey-Fuller (ADF) tests examine the null hypothesis of a unit root against a trend-stationary alternative; see Hamilton (1994) for technical details. The KPSS test examines the null hypothesis of trend-stationarity; see Kwiatkowski et al (1992). PP is robust with regard to heteroskedasticity but ignores autocorrelation beyond a finite lag window. ADF includes an autoregressive correction but ignores heteroskedasticity. To accommodate short-run dependencies, all results are reported for an AR(4) in ADF and for 12 lags in PP and in KPSS. All tests allow for a deterministic time trend in the stationary alternative.

The test results in Table 3 are statistically clear-cut. All the deficit measures appear to be stationary: ADF and PP reject a unit root while KPSS does not reject stationarity. All other variables appear to have unit roots: KPSS is rejecting trend-stationarity whereas ADF and PP are not rejecting unit roots. Importantly, one finds a stationary with-interest deficit in a setting with non-stationary revenues, outlays, and debt, a configuration that satisfies Trehan-Walsh's (1988) sustainability condition.

The results about deficits are logically inconsistent, however. The with-interest deficit is a linear function of primary deficit and debt. Given a non-stationary debt, the with-interest deficit and the primary deficit cannot both be stationary. It appears that debt has such a small weight in the withinterest deficit that the tests are not powerful enough to distinguish stationarity in $\left(-S_{t}\right)$ from stationarity in $\left(-s_{t}\right)+r_{t} \cdot d_{t-1}$. It is unclear therefore which of the deficit measures is stationary, i.e., if Trehan-Walsh's condition is satisfied.

The real time series also suffer from an enormous non-stationarity in variances. To illustrate the problem, Table 4 displays standard deviations of primary deficits and of the public debt for

\footnotetext{
${ }^{7}$ Conceptually equivalent unit root and cointegration tests may still yield different results because different methods are used to distinguish short- from long-run relationships in the data and because the equivalence is exact only if the return on debt is constant and if all variables are measured consistently. An examination of such subtle differences is beyond the scope of this paper and would distract from more important issues. See Bohn (1991b) for cointegration results about U.S. fiscal policy.
} 
selected sub-samples. The standard deviation of post-1900 real deficits exceeds the pre-1900 value by a factor 64. Even for post-WWII data (more commonly used in the literature) standard deviations are increasing over time, as illustrated by the split 1960-2003 sample. This cast some doubts on the unit root results, suggesting that the "stationary" real series in Table 3 are not truly covariance stationary. ${ }^{8}$ Table 4 also documents that the standard deviations of GDP-ratios display much less growth over time, suggesting that the rising variances of real deficits and real debt are largely due to a growing economy.

Table 5 displays unit root tests for GDP-ratios of the same variables as in Table 3. For deficits, revenues, and non-military outlays, GDP-ratios have similar properties as the real series. All the deficit-GDP series appear stationary. Revenues and non-military outlays appear to have unit roots. Different results are obtained, however, for the debt-GDP ratio, for outlays/GDP and for military spending/GDP. For the debt-GDP ratio neither stationarity nor non-stationarity is rejected; for the outlay-GDP ratio both stationarity and non-stationarity are rejected; and military spending/GDP appears to be stationary.

Scaling by GDP may raise questions about the stationarity of U.S. GDP itself, the subject of an old controversy (Christiano and Eichenbaum, 1990). In my real GDP series, trend-stationarity is rejected for 1790-2003 (KPSS=0.347) but not for 1868-2003 (KPSS=0.069). A unit root is not rejected for either sample period ( $\mathrm{PP}=-2.16$ for 1790-2003, $\mathrm{PP}=-2.67$ for 1869-2003). The evidence against a stationary GDP is weak, however, because the pre-1869 GDP data may be of lower quality than the more recent data. A unit root in real GDP is also consistent with the observation that some stationary GDP-shares in Table 5 become non-stationary when multiplied by GDP (notably public debt, see Table 3). Unit roots in Table 3 may simply reflect balanced growth without revealing much about fiscal policy.

Table 6 directly addresses the possibility that the time-series properties of real GDP might be unduly influence the results in Table 5 . In Table 6, the real variables are divided by a common

\footnotetext{
8 In addition, the unequal variances imply that the OLS estimates underlying the unit root tests essentially disregard most of the sample-all but the most recent, most volatile observations. Phillips-Perron's heteroskedasticity correction is based on a small number of autocorrelation, it's ability to correct for this trend-type of heteroskedasticity is unclear.
} 
exponential trend that captures average GDP growth for 1869-2003 (3.48 percent). The results are very similar to Table 5, documenting that differences between real series and GDP-ratios arise largely from reduced heteroskedasticity and are not induced by the time series properties of GDP.

Taking logs is a common device to remove growth in the variances of strictly positive variables (e.g., debt, revenues, and outlays, but not for deficits). Logarithms are not economically insightful here, however, because taking logs magnifies a series' fluctuations near zero, whereas sustainability is primarily about how fiscal policy recovers from high values of debt and outlays. To illustrate this point, Figure 6 displays logarithms of real U.S. debt and real GDP; the gap is the log debt-GDP ratio. Log-debt is evidently dominated by the decline to near-zero debt in the 1830s and the subsequent return to more normal values, i.e., by a period that is uninformative about sustainability. Both PP and KPSS tests for log real debt are insignificant (PP=-3.08, KPSS=0.098), so log debt provides no better statistical insights than the GDP-ratio.

In summary, the econometric analysis yields three main conclusions. First, GDP-ratios and similarly scaled series provide more credible information about the fiscal series than raw real data. Second, there is no convincing evidence that the relationship between debt and deficits involves a unit root. All the deficit-GDP ratios are unambiguously stationary, and stationarity cannot be rejected for debt-GDP ratio. The failure to reject unit root for the debt-GDP ratio does not prove a unit root. Third, certain other GDP-ratios have unit roots. Revenues/GDP and non-military outlays/GDP are clearly non-stationary. Unit root tests for overall non-interest outlays are contradictory, but the nonstationarity of the non-military component suggests that the series for non-interest outlays/GDP is best treated as non-stationary. Because the primary-deficit/GDP is found stationary, one may conclude that revenues and outlays are cointegrated with vector $(1,-1)$.

\section{Model-Based Sustainability}

This section returns to the first conceptual question about sustainability: Which fiscal policies are sustainable? The basic economic answer is that an agent's ability to borrow is constrained by other agents' willingness to lend. The question which policies are sustainable is therefore a general 
equilibrium question, a question of who the government's potential lenders are and what determines their behavior. Different assumptions about lenders lead to different conclusion about the set of sustainable policies.

Constraints that superficially resemble the ad hoc TC and IBC are obtained if one assumes that potential lenders are infinitely-lived optimizing agents and that financial markets are complete. Such agents' asset accumulation necessarily satisfies a transversality condition. Complete markets imply that agents apply a common pricing kernel to value financial assets, so the transversality conditions aggregate. Applied to government debt, the lenders' transversality condition is

$$
\liminf _{n \rightarrow \infty} E_{t}\left[u_{t, n} \cdot d_{t+n}\right] \leq 0 \quad \text { [General No Ponzi Cond.] }
$$

where $u_{t, n}$ is the economy's pricing kernel for contingent claims on period $t+n$ (see Bohn 1995). A violation of this condition (a strictly positive limit) would mean that some the debt's initial value would never be repaid, i.e., represent a Ponzi scheme. Rational lenders would not buy such debt. From the government's perspective, condition (10) is therefore a constraint, commonly known as No Ponzi Condition.

In principle, one cannot rule out debt policies for which (10) does not have a proper limit, nor policies that imply large surpluses and a negative limit in (10). Such policies would raise distracting new issues, however. So to limit the scope of this paper, it seems reasonable to assume that debt is non-negative and that the limit in (10) exists. Then (10) specializes to

$$
\lim _{n \rightarrow \infty} E_{t}\left[u_{t, n} \cdot d_{t+n}\right]=0 . \quad \text { [Simple No Ponzi Cond.] }
$$

It is important in this context to distinguish the value of particular debt securities from the value of all outstanding public debt under various contingencies. In many countries, government bonds are safe securities that carry low promised interest rates, whereas government deficits and debt are quite variable and correlated with output and other sources of systematic risk. In (10)-(11), $d_{t+n}$ refers to the debt accumulated in various states of nature under a given fiscal policy, including new securities that may have to be issued along the way. Though bonds returns must satisfy the Euler equations

$$
E_{t}\left[u_{t, n} \cdot \prod_{k=0}^{n-1}\left(1+r_{t+k}\right)\right]=1 \forall(t, n)
$$


$u_{t, n}$ generally differs from $1 / \prod_{k=0}^{n-1}\left(1+r_{t+k}\right)$, making bond returns unsuitable as discount rates in (1011). Conditions (10-11) do not imply (9); sustainability may indeed require that the ad hoc condition (9) is violated.

If one combines (11) with the debt dynamics in (5) and assumes all relevant sums converge, one obtains

$$
d_{t}^{*}=\sum_{n=0}^{\infty} E_{t}\left[u_{t, n} \cdot s_{t+n}\right]
$$

This Intertemporal Budget Constraint is derived from optimizing lender behavior. It asserts that an initial debt must be backed by the present value of future primary surpluses, but it differs from the ad hoc condition (8) because the correct discount rates for future surpluses depend on the distribution of future primary surpluses across states of nature.

Some example help illustrate how the sustainability conditions (11-12) compare to the ad hoc conditions (8-9).

\section{Example 1 [Risk Neutrality]:}

Suppose lenders are risk-neutral and have a constant rate of time preference $\beta=1 /(1+r)$. Then the pricing kernel reduces to the deterministic discount factor $u_{t, n}=\beta^{n}=1 /(1+r)^{n}$. So (11-12) reduce to $(8-9) . / / /$

The ad hoc conditions (8-9) can thus be interpreted as special cases of (11-12). More generally, (11-12) reduce to (8-9) if $u_{t, n}$ is uncorrelated with $s_{t+n}$ and with $d_{t+n}$ and consistent with a constant discount factor.

\section{Example 2 [Motivated by Ahmed-Rogers (1995)]:}

Suppose $u_{t, n}=\beta^{n} \cdot \mu\left(c_{t} / c_{t+n}\right)$ is the product of a time-preference factor $\beta^{n}$ and a marginal rate of substitution $\mu\left(c_{t} / c_{t+n}\right)$ with $\mu^{\prime}>0$ (homothetic preferences with declining marginal utility). Suppose $E_{t}\left[\mu\left(c_{t} / c_{t+n}\right)\right]=1$ for all t; and suppose marginal rates of substitution have time-invariant conditional covariances with $s_{t+n}$ in real terms, $\operatorname{cov}_{t}\left(\mu\left(c_{t} / c_{t+n}\right), s_{t+n}\right)=\sigma_{n} \forall t$. Then $\beta^{n}=E_{t}\left[u_{t, n}\right]=1 /(1+r)^{n}$ can be interpreted as the safe discount factor and

$$
E_{t}\left[u_{t, n} \cdot s_{t+n}\right]=E_{t}\left[u_{t, n}\right] \cdot E_{t}\left[s_{t+n}\right]+\beta^{n} \cdot \sigma_{n}=\left(E_{t}\left[s_{t+n}\right]+\sigma_{n}\right) /(1+r)^{n}
$$


is an expected value plus a covariance term. If $\sigma=\sum_{n \geq 0} \beta^{n} \sigma_{n}$ is finite (e.g. for bounded $\sigma_{n}$ and $\beta<1$ ), (12) reduces to

$$
d_{t}^{*}=\sum_{n=0}^{\infty} \frac{1}{(1+r)^{n}} \cdot E_{t}\left[s_{t+n}\right]+\sigma,
$$

which is equivalent to (8) plus a constant.///

Example 2 demonstrates why expected value conditions like (8-9) do not provide credible information about sustainability. If (8*) is satisfied with non-zero $\sigma$, a researcher "testing” (8) would naturally conclude that public debt includes a "bubble" of size $\sigma$. Conversely, finding (8) satisfied or violated by empirical data provides no information about (12) unless one can reliably estimate the covariances between surpluses and discount factors.

Example 2 is motivated by Ahmed and Rogers (1995), who examine sustainability in a setting similar to Example 2, namely with constant $\operatorname{cov}_{t}\left(u_{t, n}, s_{t+n}\right)$ for all $t$ and $n$. Ahmed-Rogers use this setting to argue that a stationary real with-interest deficit is necessary and sufficient for (12), and therefore informative about model-based sustainability. Example 2 serves to demonstrate the opposite, however. Following Ahmed and Rogers' necessity proof, it is straightforward to show that both (8) and (8*) imply a stationary with-interest deficit. It does not help to distinguish sustainable from unsustainable policies. (Intuitively, the constant term does not affect unit root considerations.) Ahmed and Rogers’ sufficiency proof imposes various auxiliary assumptions on the stochastic process for debt. Example 2 suggests that these assumptions are unduly restrictive. ${ }^{9}$ In conclusion, unit root analysis is suitable for testing ad-hoc sustainability, but not informative about model-based conditions like (10-12).

To what extent are differences between (8) and $\left(8^{*}\right)$ is quantitatively important? Recall from Table 1 that U.S. primary deficits were positive on average for 1792-2003. If the deficit process is ergodic, one must conclude that the unconditional expectation of U.S. primary surpluses is negative, making a zero or negative contribution to the r.h.s. of $\left(8^{*}\right)$. Table 1 suggests therefore that U.S. public

\footnotetext{
${ }^{9}$ Notably, they assume debt has an absolutely summable MA representation and then proceed to take differences of various infinite sums of innovations. In the context of Example 2, Ahmed and Rogers' constant covariance assumption would imply $\sigma=\infty$, cautioning against assuming the convergence of infinite sums in this context.
} 
debt is backed entirely by the covariance expressions in $\left(8^{*}\right)$ and $(12)$. The next example provides an interpretation.

\section{Example 3 [Stochastic Growth, adapted from Bohn (1995)]:}

For the same pricing kernel as in Example 2, suppose consumption and government outlays are fixed fractions of GDP $\left(c_{t} / Y_{t}=\bar{c}, G_{t} / Y_{t}=\bar{G}\right)$, real GDP growth $\gamma_{t}$ is i.i.d. with mean $\gamma$, public debt consists of safe securities, tax revenues vary with output growth to maintain a constant end-of-period debt-GDP ratio $D_{t} / Y_{t}=\bar{d}$. Assume zero inflation to avoid nominal/real distinctions.

A constant debt-GDP ratio requires real primary surpluses that are negatively correlated with GDP growth,

$$
s_{t+n}=T_{t+n}-\bar{G} \cdot Y_{t+n}=(1+r) \cdot D_{t+n-1}-\bar{d} \cdot Y_{t+n}=\bar{d} Y_{t+n-1} \cdot\left(1+r-\gamma_{t+n}\right)
$$

Because $\mu\left(c_{t+n-1} / c_{t+n}\right)=\mu\left[1 /\left(1+\gamma_{t+n}\right)\right]$ and $s_{t+n}$ are both decreasing in $\gamma_{t+n}$, policy (13) features a positive covariance between the pricing kernel and the primary surplus. More specifically, real debt in the No Ponzi condition must be discounted at the discount rate on GDP-indexed claims,

$$
E_{t}\left[u_{t, n} \cdot d_{t+n}\right]=\bar{d} \cdot E_{t}\left[u_{t, n} \cdot Y_{t+n}\right]=\bar{d} \frac{(1+\gamma)^{n}}{(1+R)^{n}} Y_{t}=\frac{(1+\gamma)^{n}}{(1+R)^{n}} d_{t}
$$

where $1 /(1+R) \equiv E_{t}\left[u_{t, 1} \cdot\left(1+\gamma_{t+1}\right)\right] /(1+\gamma)$. Dynamic efficiency implies $R>\gamma$ and ensures that discounted real debt converges to zero, demonstrating that a policy with constant debt-GDP ratio satisfies (11-12).

Nothing in the argument above depends on the relationship between the growth rate $\gamma$ and the interest rate $\mathrm{r}$. Because $u_{t, 1}$ and $\gamma_{t+1}$ are negatively correlated, the safe rate is unambiguously below the discount rate on GDP-indexed claims, $r<R$, and it may be below $\gamma$. If $E\left[(1+r) /\left(1+\gamma_{t}\right)\right]<1$, then $E_{t}\left[s_{t+n}\right]<0$ for all $(t, n)$. Despite negative expected surpluses, the policy is sustainable. ///

The intuition for Example 3 is that the period-by-period safety of government bonds is so highly valued by investors that the government can run negative surpluses on average, provided it promises positive payouts in "bad" states of nature, i.e., states where the ex-post realization of GDP growth is low enough that $(1+r) /\left(1+\gamma_{t}\right)>1$. The condition $E\left[(1+r) /\left(1+\gamma_{t}\right)\right]<1$ essentially 
requires a safe interest rate below the average growth rate, apart from a Jensen’s inequality term. Table 2 suggests that U.S. data satisfy this condition.

In relation to Example 2 and to Ahmed-Rogers, Example 3 illustrates the pitfalls of discounting at government bond rates. Policy (13) exhibits a positive covariance between primary deficit and pricing kernel, matching the assumptions of Example 2. But $\left(8^{*}\right)$ is not well defined for $E\left[(1+r) /\left(1+\gamma_{t}\right)\right]<1$ because the primary surplus term in $\left(8^{*}\right)$ diverges to minus infinity while the covariance term $\sigma$ diverges to plus infinity.

Example 3 also helps to illustrate the role of debt management and of asset pricing considerations. For example, if government debt in Example 3 consisted of GDP-indexed bonds, policy (13) would require positive average primary surpluses. Or, if risk aversion were to decline, government bond yields would adjust and require a different level of surpluses. To determine the complete set of sustainable government policies, one would have to specify fiscal policy in a complete way, including a specification of debt management and of state-contingent variations in primary surpluses; and the results would rely critically on asset pricing assumptions.

Finance theory unfortunately does not provide an empirically successful model for discounting safe and risky payment streams. The leading asset pricing theory—consumption CAPM— is a dismal failure when it comes to explaining empirical risk premiums (Mehra and Prescott 1985). An empirically credible, complete characterization of sustainable policies is therefore an impossible task. A more promising agenda is to strive for sufficient conditions that are robust with respect to asset pricing and debt management.

\section{Testing Model-Based Sustainability}

The second main question about sustainability is how to test if an observed policy is on a trajectory consistent with (11-12).

Because testing requires a well-defined alternative hypothesis, the first follow-up question is how to think about policies that violate (10-12). There are at least three relevant interpretations. First, fiscal policy may operate in an economy where (10) does not apply. In an overlapping generations 
economy, for example, lenders have finite planning horizons and do not impose transversality conditions. If interest rates are sufficiently low, reasonable policies will not satisfy (10-12). Conditions (10-12) may also be inapplicable in economies with incomplete markets where liquidity arguments enter into the pricing of government bonds. Bohn (1999a) provides an example where government bonds have lower transactions cost than private loans; for low levels of public debt, the government bond rate is below the GDP growth rate, leading to a violation of (10) in a dynamically efficient economy with rational, infinitely-lived agents. It is therefore an empirical question if (10) is a constraint on government policy.

Second, fiscal policy may be constrained by (10), but a continuation of the policy observed during the sample period would violate (12) in the direction of too low surpluses. This may be called an empirical violation of the sustainability conditions, or more succinctly, a non-sustainable policy. If rational investors are nonetheless buying government bonds, they must be expecting a policy shift that will support the debt. An empirical violation of sustainability can therefore be interpreted as signaling a policy shift. The shift may be an increase in taxes, a reduction in outlays, or-because revenues include transfers from the Federal Reserve—-an increased reliance on seignorage. ${ }^{10}$

Third, an empirical violation of (10-12) in the direction of too low surpluses may signal that the government will eventually default on its debt. If government bonds are traded, this scenario raises questions about the rationality of investor expectations. Rational investors should never buy the public debt at a price above the r.h.s. of (12), and they should never buy new government bonds, nor refinance maturing ones, unless the government provides credible assurances that (10) is satisfied. Though default considerations may explain minor violations of (12) if debt is measured at face value, a scenario that requires irrational investors seems implausible. In summary, empirical violations of sustainability are best interpreted as indicating either a future shift in policy or an economic environment in which policy is not constrained by (10).

10 See Section 7 for monetization and for comments on the fiscal theory of the price level. See Bohn (1991b) for tax and spending responses to deficits. Note that a violation of (11-12) in the direction of too high surpluses is consistent with (10) and cannot be ruled out. 
Turning to the search for robust sustainability conditions, a key insight is that the Euler equations $E_{t}\left[u_{t, n} \cdot \prod_{k=0}^{n-1}\left(1+r_{t+k}\right)\right]=1$ apply in any economy with well-defined pricing kernel, regardless of what that pricing kernel might be. Combining (11) and (5), one can see that a fiscal policy of zero primary surpluses always yields a limiting value of debt equal to initial debt. That is, if $s_{t+k} \equiv 0 \forall k$, then

$$
d_{t+n}=\left(\prod_{k=0}^{n}\left(1+r_{t+k}\right)\right) \cdot d_{t-1}-\sum_{j=0}^{n}\left(\prod_{k=j+1}^{n}\left(1+r_{t+k}\right)\right) \cdot s_{t+j}=\left(\prod_{k=0}^{n}\left(1+r_{t+k}\right)\right) \cdot d_{t}^{*}
$$

implies $\quad E_{t}\left[u_{t, n} \cdot d_{t+n}\right]=\left(\prod_{k=0}^{n} E_{t}\left[u_{t+k, 1}\left(1+r_{t+k}\right)\right]\right) \cdot d_{t}^{*}=d_{t}^{*}$ for all $\mathrm{n}$

so $\quad \lim _{n \rightarrow \infty} E_{t}\left[u_{t, n} \cdot d_{t+n}\right]=d_{t}^{*}$.

The key point here is not that a Ponzi scheme violates the No Ponzi condition—a reassuring fact—but that the limit value can be computed without assuming a specific asset-pricing model. Because the Euler equations apply to all financial assets, including government liabilities of any type-long-term and short-term, nominal and inflation-indexed-they impose no restrictions on debt management. Using the Ponzi scheme limit as reference point, analogous reasoning helps prove the sustainability of policies with systematically less debt accumulation.

A second key insight is that robustness with respect to debt management requires a feedback rule for the primary surplus—a rule that makes surpluses a function of initial debt. To see this, suppose primary surpluses were unresponsive to initial debt and consider a slight variation in debt management. If the policy was sustainable before, a change in debt management that increases the return on debt in one state of nature and reduces the return in another state (respecting the Euler equation) will raise initial debt in the high return state. Without a policy response, the extra debt would be unbacked by future surpluses, violating the No Ponzi condition.

The most simple feedback rule that ensures sustainability is a linear one:

Proposition 1 [Bohn (1991a, 1998)]: Suppose the primary-deficit/GDP ratio is an increasing linear function of the initial debt GDP-ratio

$$
s_{t}=\rho \cdot d_{t}^{*}+\mu_{t}
$$


for all t, where $\rho>0$ is a constant and $\mu_{t}$ is a composite of other determinants. If $\mu_{t}$ is bounded as share of GDP and if the present value of GDP is finite, then fiscal policy satisfies (11-12).///

Proposition 1 suggests that sustainability can be tested by estimating a policy rule (or reaction function) for the primary surplus/GDP. The idea of the proof is that debt growth is reduced by $(1-\rho)$ relative to a Ponzi scheme, reducing the n-period ahead debt by about a factor $(1-\rho)^{n}$. For any (small) $\rho>0$, this implies $E_{t}\left[u_{t, n} \cdot d_{t+n}\right] \approx(1-\rho)^{n} \cdot d_{t}^{*} \rightarrow 0$; the $\mu_{t}$-part turns out to be asymptotically irrelevant. ${ }^{11}$

The assumptions of Proposition 1 can be weakened in various ways, for example by allowing for non-linearity and for time-varying coefficients. A non-linear feedback rule ensures sustainability if the slope is bounded away from zero at high debt-GDP ratios. That is, if there is a finite value $\hat{d}$ and a function $f(d)$ such that $f(d) \geq \rho \cdot(d-\hat{d}) \forall d \geq \hat{d}$, then the policy rule $s_{t}=\rho \cdot f\left(d_{t}^{*}\right)+\mu_{t}$ is also sustainable (Bohn 1998). A time-varying policy rule $s_{t}=\rho_{t} \cdot d_{t}^{*}+\mu_{t}$ ensures sustainability if $\rho_{t} \geq 0 \forall t$ and if $\rho_{t}>0$ applies infinitely often (Canzoneri et al (2001). Non-linearities and timevariation may, however, raise questions about the stability of policy and hence about the plausibility of extrapolating it into the future. Prop. 1 can also be strengthened by excluding seignorage from $s_{t}$, to ensure that sustainability is not attained through monetization.

Before estimating (15), the implicit stationarity and ergodicity assumptions should be acknowledged. Stationarity is commonly assumed in applied economies, but unusually important here because sustainability can only be evaluated by extrapolating current policies into the indefinite future. In practical terms, the entire history of U.S. fiscal policy displays no more than 3-5 big movements in the debt-GDP ratio, suggesting that even decades of data are potentially unrepresentative or dominated by a single event. For this reason, my estimates below are based on longest available sample, 17922003.

\footnotetext{
11 Though Proposition 1 is asserted in Bohn (1998), the formal statement and proof were unfortunately placed into an unpublished appendix on request of the editor (available at http://econ.ucsb.edu/ bohn). Canzoneri et al. (2001) present a remarkably similar sustainability proposition, equivalent to Prop. 1 in all respects except that $\rho$ is replaced by a time-varying coefficient (see below). Prop. 1 and its proof were first circulated in Bohn (1991a) and presented at Georgetown University in January 1992.
} 
Ergodicity is critical because one only observes a single realization of history from which one must infer how policy responds to disturbances and how it would respond under various contingencies. This may be impossible. A non-linear rule may, for example, show no evidence of a feedback from debt primary surpluses if debt happens to be below $\hat{d}$ throughout the sample; or in case of a time-varying rule, all the within-sample $\rho_{t}$-values may equal zero. The ergodicity problem reinforces the notion that Proposition 1 is sufficient but not necessary. A stable, positive feedback from debt to surplus would justify calling fiscal policy sustainable, whereas a missing or seemingly unstable feedback would consistent with either a non-sustainable policy or with a data set insufficient for identification. The implicit stationarity and ergodicity assumptions apply analogously to unit root, cointegration, and VAR-based tests. They seem unavoidable because sustainability constraints are inherently forward looking.

Equation (15) also raises unit root issues. First, if the debt-GDP ratio had a unit root and $\mu_{t}$ is stationary, $\rho>0$ would imply cointegration between debt and primary surplus. Eq. (15) would then satisfy Trehan-Walsh's sustainability conditions. Table 5 indicates a stationary primary surplus, however, ruling out the case of cointegration. Second, a stationary primary surplus/GDP combined with a unit root in debt might be considered evidence against $\rho>0$. It is important therefore that there is no credible evidence for a unit root in U.S. debt/GDP. Third, unit roots require attention because their (alleged) presence can serve as convenient excuse to leave out stationary regressors-here, to avoid modeling $\mu_{t}$. But because the debt-surplus linkage seems to involve stationary variables, one cannot ignore $\mu_{t}$ without creating omitted variables problems.

Policy function (15) may also be of interest in economies where (10-12) do not necessarily apply. My intuition for such economies is that a failure of (10-12) signals an inefficiently low level of public debt. This intuition works for dynamically inefficient OG economies, where higher public debt would raise interest rates and move the economy into dynamic efficiency, increasing welfare along the way. In such economies, if public debt has declined because of some disturbance, a positive response of surpluses (as in (15)) would help restore an efficiently high level of debt. The same intuition applies to models with transactions cost where public debt is prized for its liquidity (e.g., Bohn 1999a). If the 
public’s demand for liquidity so high that the government can run Ponzi schemes at low levels of debt, an increase in public debt would be Pareto-improving. A positive response of surpluses to declines in debt should again help avoid an inefficiently low public debt.

More stringent constraints than (10) may apply in economies where the government has a limited ability to tax. As shown by McCallum (1984), the No Ponzi condition can be satisfied by policies that let the debt-GDP ratio and the tax-GDP ratio increase exponentially at a rate just marginally below the discount rate. An upper limit on tax rates would impose an upper bound on the present value of revenues on the r.h.s. of (12), i.e., an upper bound on the debt-GDP ratio. In addition, restrictions on debt management would be needed to avoid fluctuations in the return on debt that might push debt above the limit. The feedback rule (15) is promising in this context because it naturally stabilizes the debt-GDP ratio. If $\mu_{t}$ and $r_{t+1}$ are stationary, the debt-GDP ratio will fluctuate around a mean of $E\left[d_{t}^{*}\right] \approx-\bar{\mu} /[\rho-\bar{r}(1-\rho)]$. The magnitude of fluctuations around the mean and the tax limit are unfortunately difficult to estimate, and beyond the scope of this paper. One may loosely interpret the gap between the estimated mean debt and the historical maximum of debt/GDP (which was evidently sustainable) as a policy’s margin of safety against shocks.

\section{Estimating the Determinants of the Primary Surplus}

This section estimates policy functions for 1792-2003 U.S. data. The approach is similar to Bohn (1998) but applied to a longer data set. Guidance for the regression specification is obtained from tax smoothing theories of optimal taxation. Tax smoothing suggests that temporary government outlays and temporary declines in income (i.e., in the tax base) trigger higher than normal budget deficits. This suggests an empirical specification for the primary surplus of the form

$$
s_{t}=\rho \cdot d_{t}^{*}+\beta_{0}+\beta_{g} \cdot \tilde{g}_{t}+\beta_{y} \cdot \tilde{y}_{t}+\varepsilon_{t}
$$

where $\tilde{g}_{t}$ is a measure of temporary outlays, $\tilde{y}_{t}$ measures temporary output, $\varepsilon_{t}$ is a mean-zero error term, and $\left(\rho, \beta_{0}, \beta_{g}, \beta_{y}\right)$ are regression coefficients.

Finding empirical proxies for $\tilde{y}_{t}$ and $\tilde{g}_{t}$ for a long sample is a challenge, but important to identify the marginal effect of public debt. Individuals living at the time presumably had better 
information about business cycle conditions than a researcher can obtain from historical data. For economic fluctuations, I simply assume that individuals were able to distinguish trends from cycles in real time as well as an economist can do looking back, using an HP-filter to extract the trend component of log real GDP. The gap between actual value and trend is taken as proxy for $\tilde{y}_{t}$ (with positive values indicating above-trend output). Fluctuations in government outlays are dominated by wartime military spending. Because an HP-filter would impute an implausible degree of foresight about the start, end, and intensity of wars, the permanent component of military outlays/GDP is computed from an estimated AR(2) process. $^{12}$ Non-military outlays are well approximated by a random walk, i.e. have no significant temporary component. The difference between actual and estimated permanent military outlays is used as proxy for $\tilde{g}_{t}$.

Table 7 presents the main policy function estimate in Col.1 and several alternatives in Col.2-5. All estimates are OLS. To account for heteroskedasticity, both ordinary and heteroskedasticityconsistent standard errors are shown (both in brackets). Col.1 displays estimates of specification (16). The coefficient on initial debt is significantly positive, as consistent with sustainability. The coefficients on temporary output and on temporary spending are positive and negative respectively, as consistent with tax smoothing. Taking sample means of the regressors, all five regressions imply a stationary debt-GDP ratio with mean of around 25\%, far below the historical peak of above $100 \%$, suggesting a substantial margin of safety against unexpected shocks.

To examine robustness, Col.2 adds a time trend, finding no significant effect. Col.3 adds the squared deviation of public debt from its mean to explore a potential non-linearity in the surplus-todebt relationship, also finding no significant effect. Col.4 replaces $\tilde{g}_{t}$ by actual military spending to document that the benchmark results are insensitive to alternative specifications for $\tilde{g}_{t}$. As motivation, note that for any Markov process, temporary and permanent components are linear in the current value. Hence Col.4 yields consistent estimates for $\rho$ for any Markov specification for military outlays. Col.5 replaces the primary surplus by the primary surplus excluding seignorage (transfers from

\footnotetext{
12 The estimated AR(2) process is $g_{t}^{\text {mil }}=0.59 \%+1.28 g_{t-1}^{\text {mil }}-0.43 g_{t-2}^{\text {mil }}$ plus error term. The permanent component is computed with a discount rate of 2 percent.
} 
Federal Reserve to Treasury). The coefficients are virtually unchanged and document that the debt-tosurplus feedback is not due to monetization.

Quite different results are obtained if one omits proxies for $\tilde{y}_{t}$ and $\tilde{g}_{t}$. This is documented in Table 8. Col.1 displays a VAR-style estimate of the surplus-debt relationship, in the spirit of Canzoneri et al. (2001). Initial debt still has a positive impact on the surplus, but the impact is smaller and less significant. In Col.2, which displays a simple bivariate regression, the coefficient on debt is near zero and insignificant. The small coefficients in Col.1-2 are suggestive of an omitted variables bias. To reinforce this point, Col.3 returns to specification (16) but with the lagged primary surplus and lagged debt as additional regressors. Though the lagged surplus is significant, the estimates are similar to Table 7 and the coefficient on debt is above 0.10 .

An omitted variables problem may also explain the failure to reject a unit root for the debtGDP ratio in Table 5. If one includes $\tilde{y}_{t}$ and $\tilde{g}_{t}$ into an ADF-regression for the debt-GDP ratio (not tabulated), the t-statistic on lagged debt jumps to -4.0 in an otherwise identical specification (vs. -2.86 in Table 5). The latter indicates significant mean-reversion even at Dickey-Fuller critical values;. The impact of $\tilde{y}_{t}$ and $\tilde{g}_{t}$ suggests omitted variables bias in the standard ADF regressions - not under the unit root null, but under the alternative, leading to a lack of power.

All specifications with $\tilde{y}_{t}$ and $\tilde{g}_{t}$ yield estimates for $\rho$ in the 0.10 to 0.12 range. This is substantial above my previous 1916-1995 estimates of about 0.05 (Bohn 1998). A closer examination of the time series suggests that the higher coefficients here are due to the interaction of public debt and military spending during the Cold War era (narrowly defined, 1954-1964; more broadly, 1954-1989). Because $20^{\text {th }}$ century samples are dominated by this period, the longer sample helps to put it in perspective.

The Cold War era is important empirically because it displays both a major decline in the debt-GDP ratio — the key phenomenon for sustainability—and a persistently above-average level of military outlays. Military outlays exceeded 10\% of GDP for 1951-64 and remained above 6\% until 1989, far above the $4 \%$ sample mean. These persistently above-average outlays are in contrast to the quick declines in military outlays after previous wars. 
In their classic articles on tax smoothing, Barro (1986a,b) and Sahasakul (1986) follow Barro’s (1981) modeling of military outlays as non-stationary. Using 1932-78 data, Barro (1981) regressed the first difference of military outlays on the casualty rate in major wars and on military capital. The implied series for permanent military outlays tracks actual outlays quite closely in the post-1953 period. That is, Cold War military outlays are treated as permanent, not as temporary spending that might justify budget deficits. The above-average surpluses during 1955-64 are then interpreted as a modest response to a far-above-average debt-GDP ratio, consistent with $\rho \sim 0.05$.

In Table 7, in contrast, temporary outlays are based on a stationary model for the military outlays/GDP ratio, as is consistent with the unit root tests in Table $5 .{ }^{13}$ The estimated mean-reversion is fast enough that above-average outlays are interpreted as largely temporary. If interpreted as temporary, the high outlays during the Cold War should have triggered below-average surpluses. Then the observed above-average surpluses can only be interpreted as a strong response to the high postWWII debt-GDP ratios, consistent with $\rho \sim 0.12$.

Table 9 documents the implications of different measures for $\tilde{g}_{t}$. Col.1 uses Barro’s measure for 1916-1995 (a sample limited by data availability). For comparison, Col.2 displays results for my benchmark specification restricted to the same sample. The Barro-style specification yields a much smaller response to initial debt, $\rho \sim 7 \%$ in Col.1 versus $\rho \sim 14 \%$ in Col.2.

It is an open question if the stationary representation or Barro's measure better represents public perceptions of Cold War outlays. If the Cold War was perceived as a regime switch, it may be appropriate to use different estimates for $\tilde{g}_{t}$ for different subsamples. In this spirit, Col.3 uses Barro's $\tilde{g}_{t}$-measure for 1916-1995 and my AR(2) measure for all other years. This yields a full sample estimate for $\rho$ of 6.9\%. (Using Barro’s measure for 1946-1965 only would yield a similar value, 7.2\%.)

Overall, reasonable estimates for the surplus-to-debt response range from $6.9 \%$ to $12.1 \%$ (using Table 9, Col.3 and Table 7, Col.1), depending on the interpretation of Cold War spending. The

\footnotetext{
13 Apart from the stationarity issue, Barro’s (1981) specification for military outlays becomes unworkable when applied sample periods that include the Civil War. Civil War casualties were so high that Barro's regression coefficients would predict negative outlays; or if one constrained the coefficients to avoid negative values, casualty rates would become irrelevant for other periods.
} 
Cold War interpretation is just quantitative issue, however. Sustainability is satisfied for either interpretation because all estimates for $\rho$ are significantly positive.

\section{Related Issues}

This section briefly addresses three issues related to sustainability—seignorage, the fiscal theory of the price level, and the measurement of public liabilities. Neither will affect the findings above, but they should be clarified to avoid unnecessary questions.

Because Treasury revenues include Federal Reserve transfers, the IBC could be satisfied in principle by a fiscal authority that is oblivious to accumulating debt and a central bank that monetizes the debt. This would make seignorage the debt-responsive component of the primary surplus. For the U.S., seignorage is empirically trivial, however, averaging to $0.16 \%$ of GDP for $1915-2003$. In Table 1, primary surpluses would be negative on average even if one excluded seignorage. In Table 7, Col.5 documents the negligible role of seignorage. Debt and seignorage actually have a slightly negative correlation, providing no indication that debt is monetized. Seignorage is also an issue during the Greenback period of 1862-1879. Public debt includes non-interest bearing debt such as Greenbacks, but because no interest payments are involved, the primary surpluses are unaffected.

The fiscal theory of the price level (FTPL) treats equations like (8) or (12) as equilibrium conditions for the market value of government debt rather than constraints (e.g., Cochrane 1988). This is related to the default-story for violations of (10) discussed in Section 5, but with more specific assumptions. Lenders' rationality and the No Ponzi condition are taken for granted and debt is assumed nominal. Its value is equated to the present value of surpluses through endogenous changes in the nominal price level.

The FTPL unfortunately starts off with a pre-existing nominal debt and ignores the conditions under which such debt can be issued. Once a debt is outstanding, the government has obvious incentives to default. This applies not only to nominal debt and inflation, but to any type of debt because a sovereign government can always declare a default. The No Ponzi condition implies that rational lenders will not buy government bonds unless the government can commit to return the 
present value—not necessarily deterministically but in present value. The FTPL thus implicitly assumes that lenders allow the government to pursue time-inconsistent policies.

From a starting position with no debt, the IBC is clearly a constraint. Indeed, a government that can't commit to honor its debt will have to run balanced budgets on a period-by-period basis, or maintain reserves. With rational lenders, a commitment to satisfy the No Ponzi condition is precisely the commitment the government has to make to sell bonds. Once made, such a commitment is reasonably called a constraint. Thus, the FTPL does not invalidate the intertemporal budget constraint.

Another challenge for testing sustainability is the question how to treat implicit government obligations that are not recognized as official debts. In the U.S., the main ones are commitments to social security and Medicare. The Unified Budget accounts for these programs as discretionary transfer schemes. One alternative is to treat the present value of accrued obligations (say, using corporate defined benefit pension accounting) as a liability and to examine its sustainability like the sustainability of public debt. This approach is unfortunately problematic because social security obligations are difficult to value (see Bohn 1992) and because the available data are inherently nonstationary-historically because of the "first generation” startup/expansion phase and prospectively because of the baby boom. A second alternative is to treat social security and Medicare as political commitments and examine their political sustainability. Pursuing this approach, Bohn (1999b) and (2004) find that both social security and Medicare are sustainable in the sense that substantial majority of U.S. voters will have financial incentives to vote for their continuation, now and in the foreseeable future.

\section{Conclusions}

The paper examines the sustainability of U.S. fiscal policy, finding substantial evidence in favor. I first summarize the U.S. fiscal record from 1792-2003 and show that growth effects have historically covered the entire interest cost of the U.S. debt. I then review sustainability conditions based on expected-value budget constraints and provide a unified presentation of the implied unit root tests. I conclude that fiscal series not scaled by GDP are misleading in the context of unit root testing and that 
there is no credible evidence of a unit roots in the U.S. debt-GDP and deficit-GDP ratios. The main evidence in favor of sustainability is the finding of a robust positive response of primary surpluses to variations in initial debt. The policy functions for primary surpluses are similar to Bohn (1998), but the longer 1793-2003 sample places less emphasis on WWII and on the Cold War. 


\section{References}

Abel, Andrew, Gregory Mankiw, Larry Summers, and Richard Zeckhauser, 1989, Assessing Dynamic Efficiency: Theory and Evidence, Review of Economic Studies 56, 1-20.

Ahmed, Shaghil and John Rogers, 1995, Government budget deficits and trade deficits: Are present value constraints satisfied in long-term data? Journal of Monetary Economics 36, 351-374.

Barro, Robert J., 1981, Output Effects of Government Purchases, Journal of Political Economy 89, 1086-1121.

1986a, U.S. Deficits since World War I, Scandinavian Journal of Economics 88, 195-222.

1986b, The Behavior of United States Deficits, in R. Gordon, ed., The American Business

Cycle: Continuity and Change, University of Chicago Press, Chicago, Ill.

Beveridge, Stephen, and Charles Nelson, 1981, A new approach to decomposition of economic time series into permanent and transitory components with particular attention to measurement of the business cycle, Journal of Monetary Economics 7, 151-174.

Bohn, Henning, 1991a, Testing the Sustainability of Budget Deficits in a Stochastic Economy, mimeo, University of Pennsylvania.

1991b, Budget Balance through Revenue or Spending Adjustments? Some Historical Evidence for the United States, Journal of Monetary Economics 27, June 1991, 333-359. 1992, Budget Deficits and Government Accounting, Carnegie-Rochester Conference Series on Public Policy 37, December 1992, 1-84.

, 1995, The Sustainability of Budget Deficits in a Stochastic Economy, Journal of Money, Credit, and Banking 27, February 1995, 257-271.

, 1998, The Behavior of U.S. Public Debt and Deficits, The Quarterly Journal of Economics, August1998, 949-963.

1999a, Fiscal Policy and the Mehra-Prescott Puzzle: On the Welfare Implications of Budget

Deficits when Real Interest Rates are Low, Journal of Money, Credit, and Banking 31, February 1999, 1-13.

1999b, Will Social Security and Medicare Remain Viable as the U.S. Population is Aging? Carnegie-Rochester Conference Series on Public Policy 50, June 1999, 1-53.

, 2004, Will Social Security and Medicare Remain Viable as the U.S. Population is Aging?

An Update, in: Robin Brooks and Assaf Razin (eds.), The Politics and Finance of Social Security Reform, Cambridge University Press, forthcoming.

Canzoneri, Matthew, Robert Cumby, and Bezhad Diba, 2001, Is the Price Level Determined by the Needs of Fiscal Solvency? American Economic Review, December 2001, 1221-1238.

Christiano, Larry, and Martin Eichenbaum, 1990, Unit Roots and in real GNP: Do we know, and do we care? Carnegie-Rochester Conference Series on Public Policy 32, 7-62. 
Cochrane, John, 1988, A Frictionless View of U.S. Inflation, in: Ben Bernanke and Julio Rotemberg (eds.), NBER Macroeconomics Annual, 323-384.

Hansen, Lars, William Roberds, and Thomas Sargent, 1991, Time Series Implications of Present Value Budget Balance and of Martingale Models of Consumption and Taxes, in: Lars Hansen and Thomas Sargent, Rational Expectations Econometrics, Boulder: Westview Press, 1991.

Hamilton, James, and Majorie Flavin, 1986, On the Limitations of Government Borrowing: A Framework for Empirical Testing, American Economic Review 76, 808-819.

Hamilton, James, 1994, Time Series Analysis, Princeton: Princeton University Press.

Kwiatkowski, Denis, Peter Phillips, Peter Schmidt, and Yongcheol Shin, 1992, Testing the null hypothesis of stationarity against the alternative of a unit root, Journal of Econometrics 54, 159178.

McCallum, Bennett, 1984, Are Bond-financed Deficits Inflationary? A Ricardian Analysis, Journal of Political Economy 92, 125-135

Mehra, Rajnish, and Edward Prescott, 1985, The Equity-Premium: A Puzzle, Journal of Monetary Economics 15, 145-162.

Sahasakul, Chaipat, 1986, The U.S.-Evidence of Optimal Taxation Over Time, Journal of Monetary Economics 18, 251-275.

Trehan, Bharat, and Carl Walsh, 1988, Common Trends, The Government Budget Constraint, and Revenue Smoothing, Journal of Economic Dynamics and Control 12, 425-444.

Trehan, Bharat, and Carl Walsh, 1991, Testing Intertemporal Budget Constraints: Theory and Applications to U.S. Federal Budget and Current Account Deficits, Journal of Money, Credit and Banking 23, 210-223.

Wickens, M.R, and Merih Uctum, 1993, The Sustainability of Current Account Deficits, Journal of Economic Dynamics and Control, 423-441. 
Figure 1: The U.S. Budget Deficit

Nominal \$bill, 1900-2003

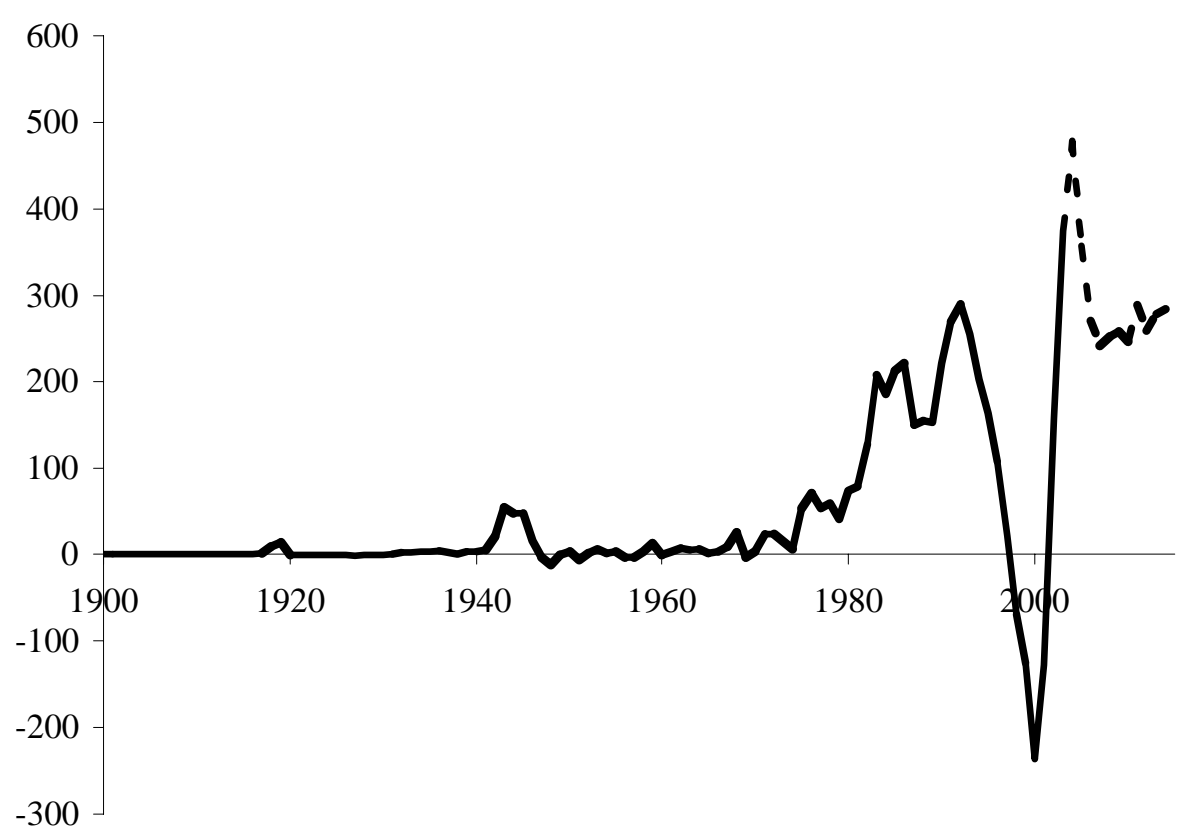

Figure 2: The U.S. Public Debt,

Nominal (line) and real (dotted), 1900-2003

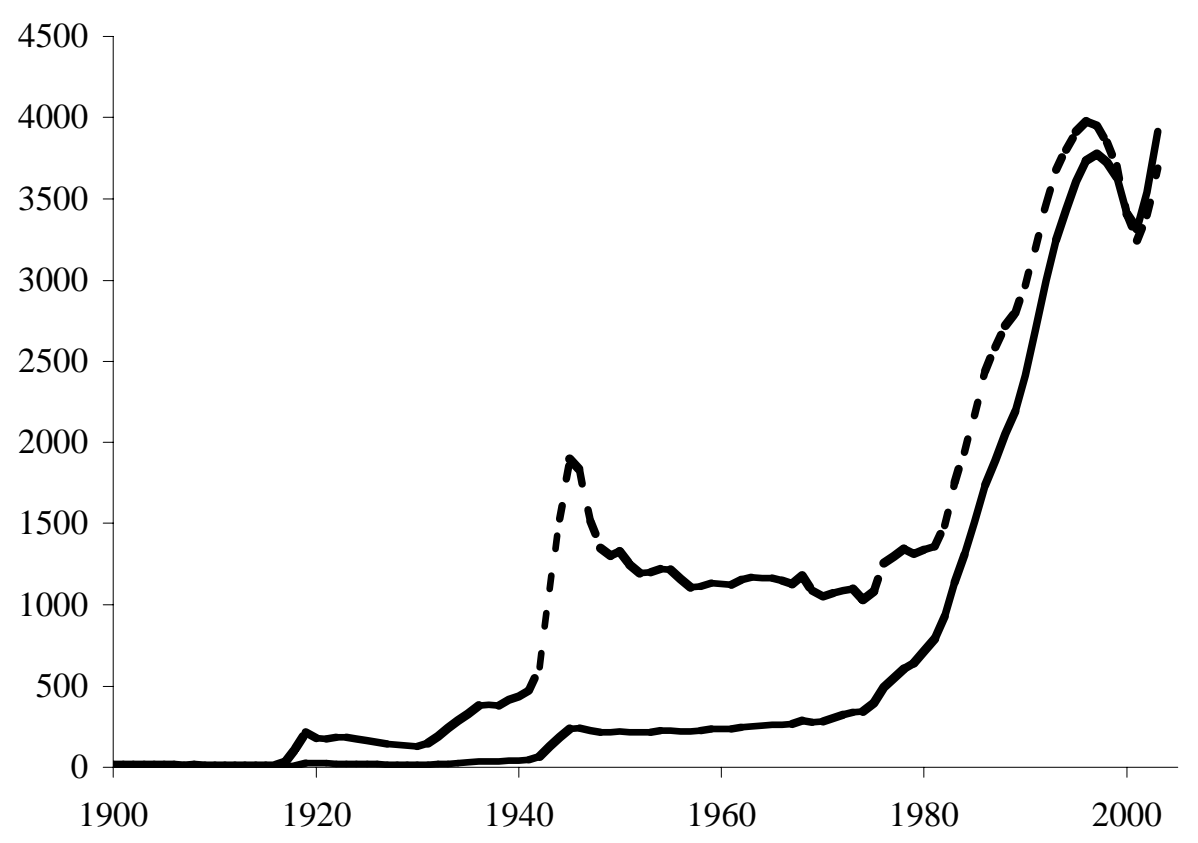


Figure 3: The U.S. Public Debt in Percent of GDP

1791-2003

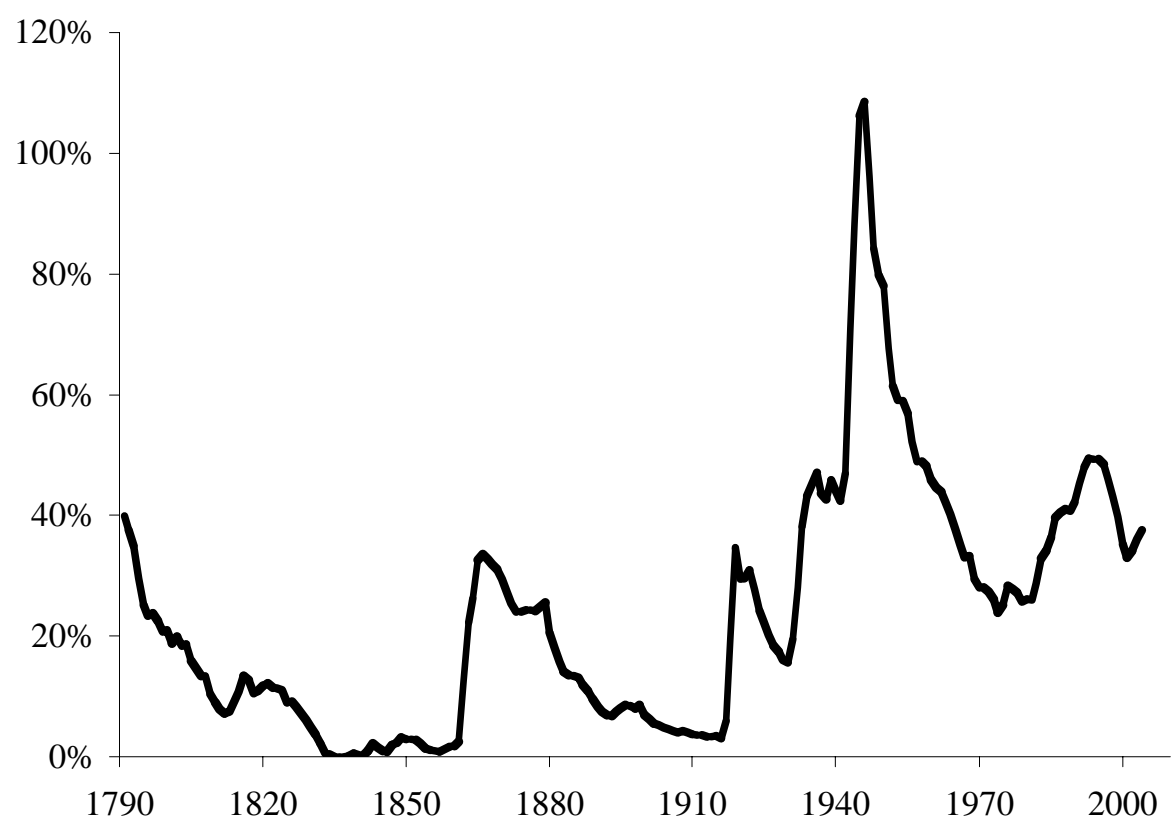

Figure 4: The U.S. Deficit in Percent of GDP

1792-2003

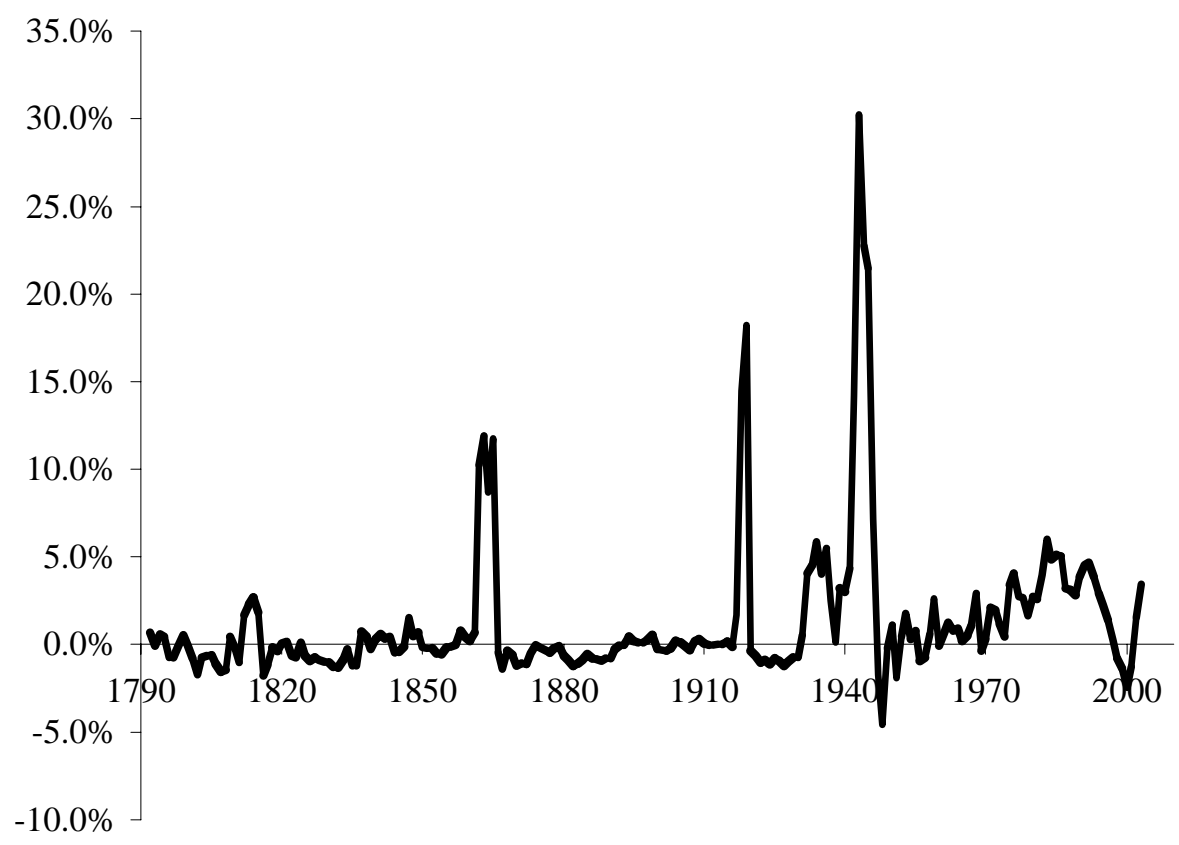


Figure 5: Revenues and Outlays in Percent of GDP

1791-2003

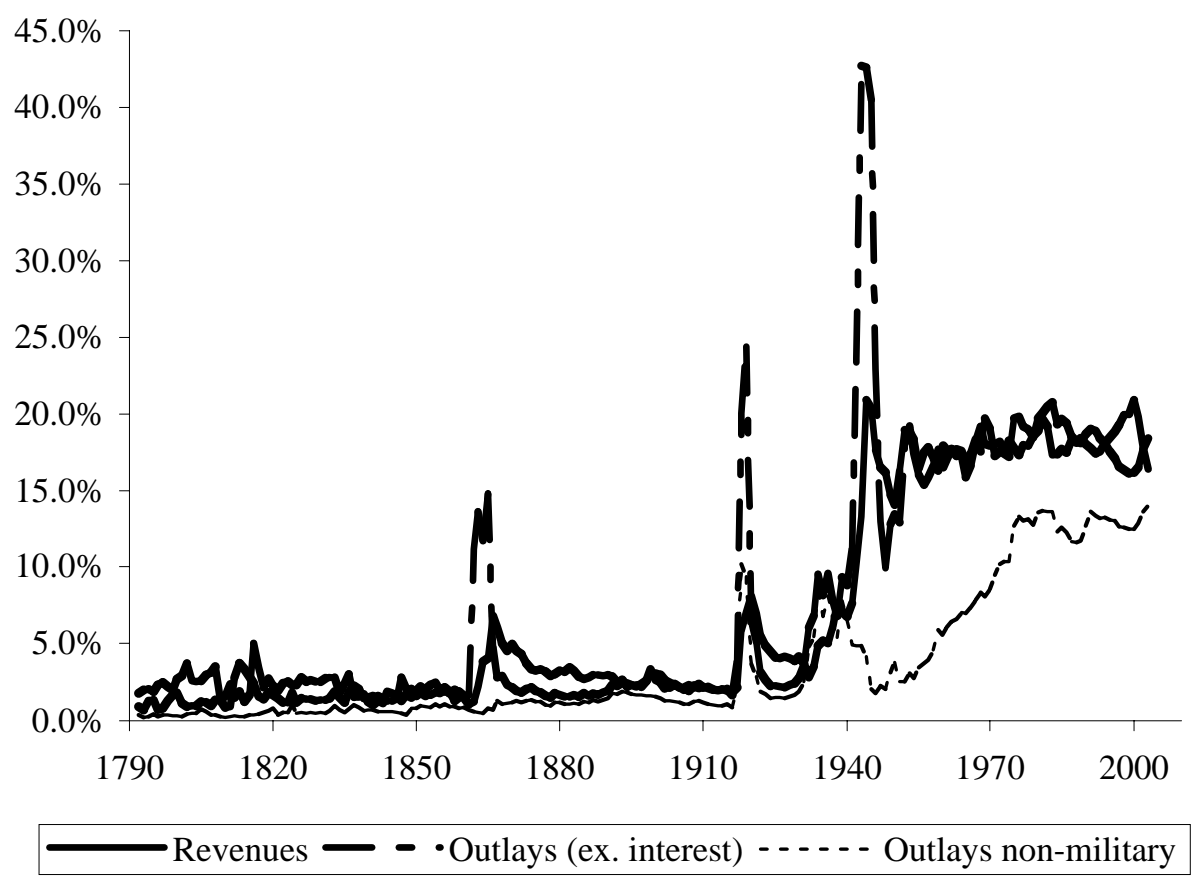

Figure 6: Logarithms of real debt and real GDP

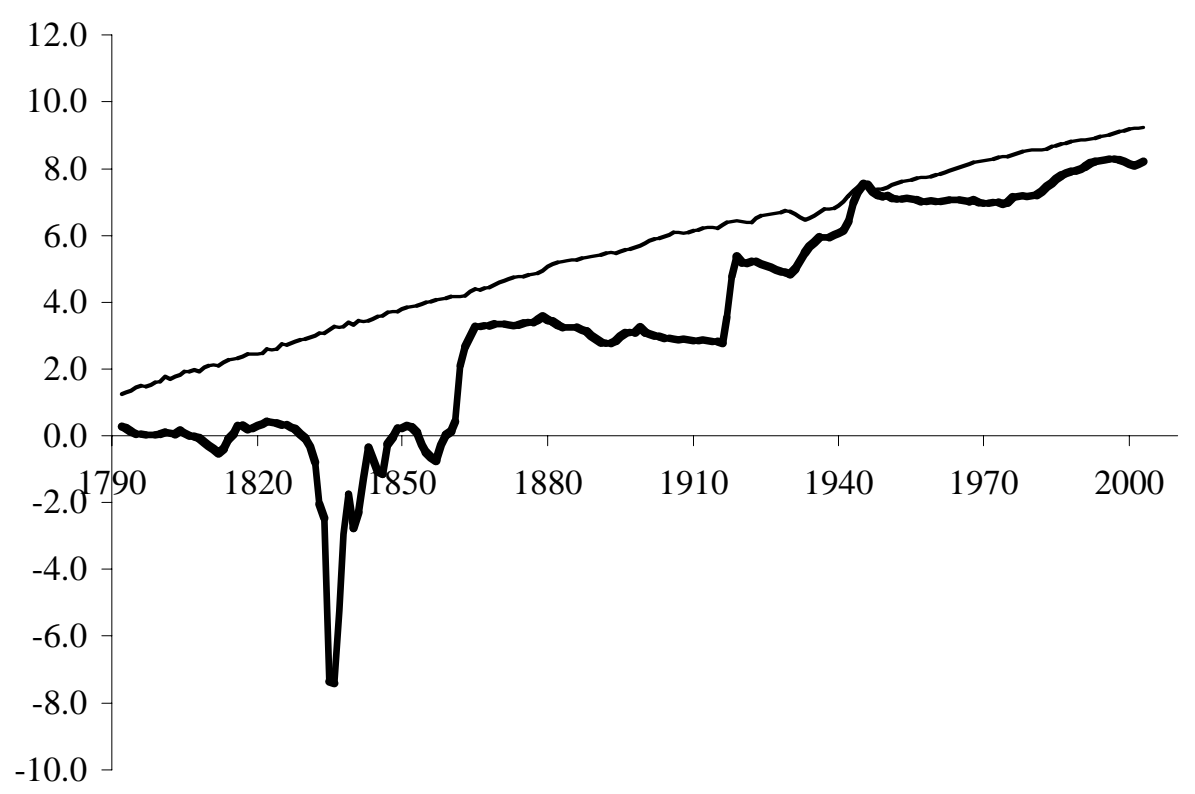

Log Debt - - - - - Log GDP 
Table 1: Deficits versus Changes in the Debt-GDP Ratio

\begin{tabular}{lcccccccc}
\hline $\begin{array}{l}\text { Period: } \\
\text { From }\end{array}$ & To & $\begin{array}{c}\text { With } \\
\text { interest } \\
\text { Deficit }\end{array}$ & $\begin{array}{c}\text { Primary } \\
\text { Deficit }\end{array}$ & $\begin{array}{c}\text { Interest } \\
\text { Charge }\end{array}$ & $\begin{array}{c}\text { Nominal } \\
\text { Growth } \\
\text { Effect }\end{array}$ & $\begin{array}{c}\text { Real } \\
\text { Growth } \\
\text { Effect }\end{array}$ & $\begin{array}{c}\text { Inflation } \\
\text { Effect }\end{array}$ & $\begin{array}{c}\text { Change in } \\
\text { Debt/GDP }\end{array}$ \\
& & $(1)$ & $(2)$ & $(3)$ & $(4)$ & $(5)$ & $(6)$ & $(7)$ \\
\hline $\mathbf{1 7 9 2}$ & $\mathbf{2 0 0 3}$ & $\mathbf{1 . 2 \%}$ & $\mathbf{0 . 3 \%}$ & $\mathbf{0 . 9} \%$ & $\mathbf{1 . 3 \%}$ & $\mathbf{0 . 8} \%$ & $\mathbf{0 . 5 \%}$ & $\mathbf{0 . 0} \%$ \\
\hline 1792 & 1868 & $0.4 \%$ & $-0.1 \%$ & $0.5 \%$ & $0.6 \%$ & $0.5 \%$ & $0.1 \%$ & $-0.1 \%$ \\
1869 & 2003 & $1.7 \%$ & $0.5 \%$ & $1.2 \%$ & $1.7 \%$ & $1.0 \%$ & $0.7 \%$ & $0.0 \%$ \\
\hline 1792 & 1914 & $0.1 \%$ & $-0.4 \%$ & $0.5 \%$ & $0.5 \%$ & $0.5 \%$ & $0.0 \%$ & $-0.3 \%$ \\
1915 & 2003 & $2.8 \%$ & $1.2 \%$ & $1.6 \%$ & $2.4 \%$ & $1.2 \%$ & $1.2 \%$ & $0.4 \%$ \\
\hline
\end{tabular}

Table 2: Interest Rates on Public Debt versus Growth Rates

\begin{tabular}{lcccccc}
\hline $\begin{array}{l}\text { Period: } \\
\text { From }\end{array}$ & To & $\begin{array}{c}\text { Interest } \\
\text { Rate }\end{array}$ & $\begin{array}{c}\text { Nominal } \\
\text { Growth }\end{array}$ & $\begin{array}{c}\text { Real } \\
\text { Growth }\end{array}$ & Inflation & $\begin{array}{c}\text { Interest- } \\
\text { Growth }\end{array}$ \\
& & $(1)$ & $(2)$ & $(3)$ & $(4)$ & $(5)$ \\
\hline $\mathbf{1 7 9 2}$ & $\mathbf{2 0 0 3}$ & $\mathbf{4 . 5 \%}$ & $\mathbf{5 . 2 \%}$ & $\mathbf{3 . 8 \%}$ & $\mathbf{1 . 4 \%}$ & $\mathbf{- 0 . 6 \%}$ \\
\hline 1792 & 1868 & $4.8 \%$ & $4.9 \%$ & $4.2 \%$ & $0.6 \%$ & $-0.1 \%$ \\
1869 & 2003 & $4.4 \%$ & $5.3 \%$ & $3.5 \%$ & $1.8 \%$ & $-1.0 \%$ \\
\hline 1792 & 1914 & $4.6 \%$ & $4.3 \%$ & $4.1 \%$ & $0.2 \%$ & $0.4 \%$ \\
1915 & 2003 & $4.4 \%$ & $6.4 \%$ & $3.4 \%$ & $3.1 \%$ & $-2.1 \%$ \\
\hline
\end{tabular}


Table 3: Unit Root Tests for Real Fiscal Variables, 1792-2003

\begin{tabular}{|c|c|c|c|c|}
\hline Variable & $\mathrm{PP}(12)$ & $\mathrm{ADF}(4)$ & KPSS(12) & Verdict \\
\hline Public Debt & -0.289 & -0.174 & $0.325 * *$ & Unit root \\
\hline Deficit, primary & $-3.787 *$ & $-5.814 * *$ & 0.076 & Stationary \\
\hline Deficit $(-s+r \cdot d)$ & $-4.143 * *$ & $-5.658 * *$ & 0.058 & Stationary \\
\hline Deficit $D E F / P$ & $-3.578 *$ & $-4.757 * *$ & 0.134 & Stationary \\
\hline Revenues total & +1.614 & +2.284 & $0.370 * *$ & Unit root \\
\hline Outlays: non-interest & +2.799 & +1.692 & $0.380 * *$ & Unit root \\
\hline Outlays: military & -2.577 & -2.804 & $0.349 * *$ & Unit root \\
\hline Outlays: non-military & +7.144 & +4.558 & $0.331 * *$ & Unit root \\
\hline \multirow[t]{2}{*}{ Critical Values: 5\% } & -3.432 & -3.432 & 0.146 & \\
\hline & -4.004 & -4.004 & 0.216 & \\
\hline
\end{tabular}

Notes: $* / * *=$ significant at $5 \% / 1 \%$. PP(12) $=$ Phillips-Perron test with 12 -year autocorrelation window; $\mathrm{ADF}(4)=$ Augmented Dickey-Fuller test with 4-th order autocorrelation; KPSS(12) = Kwiatkowski et al (1992) test with 12-year autocorrelation window. Verdict $=$ Unit root if KPSS rejects and PP/ADF not; stationary, if ADF or PP reject and KPSS not.

Table 4: Standard Deviations of Fiscal Variables

\begin{tabular}{l|ccc|ccc|}
\cline { 2 - 7 } & \multicolumn{7}{|c|}{ Split 1792-2003 sample in 1900 } & \multicolumn{3}{|c|}{ Split 1960-2003 sample in 1980 } \\
& $1792-1899$ & $1900-2003$ & Ratio & $1960-1980$ & $1981-2003$ & Ratio \\
\hline Real Variables & $(1)$ & $(2)$ & $(3)$ & $(4)$ & $(5)$ & $(6)$ \\
\hline Primary Deficit & 1.8 & 114.7 & 64.0 & 48.2 & 184.5 & 3.8 \\
Public Debt & 11.9 & 1174.3 & 98.3 & 95.2 & 832.4 & 8.7 \\
\hline GDP-shares & & & & & & \\
Primary Deficit/GDP & $2.29 \%$ & $5.12 \%$ & 2.2 & $1.15 \%$ & $2.20 \%$ & 1.9 \\
Public Debt/GDP & $9.96 \%$ & $22.44 \%$ & 2.3 & $7.22 \%$ & $6.82 \%$ & 0.9 \\
\hline
\end{tabular}

Notes: Entries in col.1-2 and col.4-5 are standard deviations. The ratios in Col.3\&6 are the two standard deviation values to the left of the ratio column. 
Table 5: Unit Root Tests for GDP-shares, 1792-2003

\begin{tabular}{lllll}
\hline Variable & PP(12) & ADF(4) & KPSS(12) & Verdict \\
\hline Public Debt & -2.834 & -2.861 & 0.118 & No rejection \\
Deficit, primary & $-5.076^{* *}$ & $-5.587^{* *}$ & 0.073 & Stationary \\
Deficit $(-s+r \cdot d)$ & $-6.354^{* *}$ & $-6.617^{* *}$ & 0.075 & Stationary \\
Deficit $D E F / Y$ & $-5.106 * *$ & $-5.594 * *$ & 0.047 & Stationary \\
Revenues total & -2.058 & -1.971 & $0.328 * *$ & Unit root \\
Outlays: non-interest & $-3.882 *$ & $-3.766^{* *}$ & $0.236 * *$ & All rejected \\
Outlays: military & $-3.593 *$ & $-3.610 *$ & 0.102 & Stationary \\
Outlays: non-military & -2.145 & -1.913 & $0.334 * *$ & Unit root \\
\hline \multicolumn{1}{c}{ Critical Values: $5 \%$} & -3.432 & -3.432 & 0.146 & \\
\hline $1 \%$ & -4.004 & -4.004 & 0.216 &
\end{tabular}

Notes: See Table 3.

Table 6: Unit Root Tests for Detrended Real Series, 1792-2003

(Scaled by common exponential trend for GDP)

\begin{tabular}{|c|c|c|c|c|}
\hline Variable & $\mathrm{PP}(12)$ & $\operatorname{ADF}(4)$ & KPSS(12) & Verdict \\
\hline Public Debt & -2.770 & -3.017 & 0.100 & No rejection \\
\hline Deficit, primary & $-4.942 * *$ & $-5.579 * *$ & 0.049 & Stationary \\
\hline Deficit $(-s+r \cdot d)$ & $-5.702 * *$ & $-6.135 * *$ & 0.047 & Stationary \\
\hline Deficit $D E F / Y$ & $-4.943 * *$ & $-5.568 * *$ & 0.068 & Stationary \\
\hline Revenues total & -2.321 & -2.251 & $0.295 * *$ & Unit root \\
\hline Outlays: non-interest & $-3.916 *$ & $-4.074 *$ & $0.208 *$ & All rejected \\
\hline Outlays: military & $-3.661 *$ & $-3.877 *$ & 0.098 & Stationary \\
\hline Outlays: non-military & -2.227 & -1.813 & $0.330 * *$ & Unit root \\
\hline \multirow[t]{2}{*}{ Critical Values: $5 \%$} & -3.432 & -3.432 & 0.146 & \\
\hline & -4.004 & -4.004 & 0.216 & \\
\hline
\end{tabular}

Notes: See Table 3. In contrast to Table 3, all variables were divided by an exponential trend with growth rate $3.48 \%$, the average growth rate of real log-GDP for 1869-2003. 
Table 7: Determinants of the Primary Surplus/GDP, 1793-2003

(Dependent variable: $s_{t}$ in Percent of GDP)

\begin{tabular}{|c|c|c|c|c|c|}
\hline Coefficient on: & Main Model & $\begin{array}{l}\text { With debt- } \\
\text { squared } \\
(2)\end{array}$ & $\begin{array}{l}\text { With time } \\
\text { trend } \\
\text { (3) }\end{array}$ & $\begin{array}{l}\text { With AR(1) } \\
\text { for outlays } \\
\text { (4) }\end{array}$ & $\begin{array}{l}\text { With surplus } \\
\text { ex. seignorage } \\
\text { (5) }\end{array}$ \\
\hline \multirow[t]{2}{*}{ Initial Debt $d_{t}^{*}$} & 0.121 & 0.094 & 0.116 & 0.117 & 0.119 \\
\hline & $(11.3 ; 8.6)$ & $(11.6 ; 8.2)$ & $(10.1 ; 8.3)$ & $(11.3 ; 8.6)$ & $(11.3 ; 8.6)$ \\
\hline \multirow[t]{2}{*}{ Constant } & -.030 & -.030 & -0.033 & 0.0003 & -.031 \\
\hline & $(-10.6 ;-8.4)$ & $(-10.4 ;-8.7)$ & $(-8.7 ;-8.4)$ & $(0.1 ; 0.2)$ & $(-10.9 ;-8.7)$ \\
\hline Temporary & 0.088 & 0.087 & 0.091 & 0.085 & 0.090 \\
\hline output $\tilde{y}_{t}$ & $(2.2 ; 1.9)$ & $(2.1 ; 1.8)$ & $(2.2 ; 2.0)$ & $(2.1 ; 1.8)$ & $(2.2 ; 2.0)$ \\
\hline Temporary & -0.815 & -0.817 & -0.823 & -0.742 & -0.818 \\
\hline outlays $\tilde{g}_{t}$ & $(-19.6 ;-11.0)$ & $(-19.6 ;-11.0)$ & $(-19.5 ;-11.2)$ & $(-20.0 ;-11.4)$ & $(-19.9 ;-11.3)$ \\
\hline Squared debt & & 0.020 & & & \\
\hline$\left(d_{t}^{*}-\bar{d}\right)^{2}$ & & $(0.8 ; 0.8)$ & & & \\
\hline \multirow[t]{2}{*}{ Time Trend } & & & $3 * 10^{-5}$ & & \\
\hline & & & $(1.0 ; 1.45)$ & & \\
\hline R-squared & 0.689 & 0.691 & 0.691 & 0.690 & 0.697 \\
\hline
\end{tabular}

Notes: Estimates of equation (16) in the text. Entries are coefficient estimates. Entries in brackets are the ordinary tstatistics and heteroskedasticity-consistent t-statistics, respectively. Temporary outlays are computed as different between actual military outlays from their permanent component as implied by an AR(2) process, except in Col.4. Col. 4 uses actual military outlays as regressor, as explained in the text. 
Table 8: The Implications of Omitted Variables

(Dependent variable: $s_{t}$ in Percent of GDP)

\begin{tabular}{clcc}
\hline Model: & VAR style & Bivariate & Eq.(16) \& VAR \\
& regression & regression & style regressors \\
Coefficient on: & $(1)$ & $(2)$ & $(3)$ \\
\hline Initial Debt $d_{t}^{*}$ & 0.028 & -0.018 & 0.104 \\
& $(2.8 ; 2.1)$ & $(-1.3 ;-0.8)$ & $(10.8 ; 6.3)$ \\
Lagged Surplus & 0.957 & & 0.366 \\
$s_{t-1}$ & $(10.0 ; 3.7)$ & & $(4.2 ; 2.5)$ \\
Change in Debt & 0.217 & & -0.007 \\
$d_{t}^{*}-d_{t-1}^{*}$ & $(2.3 ; 1.0)$ & & $(-0.1 ;-0.1)$ \\
Constant & -0.007 & 0.001 & -0.026 \\
R-squared & $(-2.3 ;-2.0)$ & $(0.3 ; 0.3)$ & $(-9.8 ;-6.1)$ \\
Temporary & & & 0.099 \\
outlays $\tilde{g}_{t}$ & & & $(2.8 ; 2.7)$ \\
\hline
\end{tabular}

Notes: Specifications as in Table 7 unless noted. The VAR-style regressions show the change in debt $d_{t}^{*}-d_{t-1}^{*}$ ss regressor instead of the lagged debt $d_{t-1}^{*}$ to highlight the permanent effects of debt on surpluses and to avoid collinearity. If $d_{t-1}^{*}$ were entered instead of $d_{t}^{*}-d_{t-1}^{*}$ in Col.1 and Col.3, neither would be individually significant, but the sum would be as significantly positive as the initial debt coefficients above. 


\section{Table 9: Alternative Measures of Temporary Outlays (Dependent variable: $s_{t}$ in Percent of GDP)}

\begin{tabular}{cccc}
\hline Model: & Barro's $\tilde{g}_{t}$ & AR(2) for $\tilde{g}_{t}$ & Spliced $\tilde{g}_{t}$ \\
& $1916-1995$ & $1916-2003$ & $1793-2003$ \\
Coefficient on: & $(1)$ & $(3)$ & $(2)$ \\
\hline Initial Debt $d_{t}^{*}$ & 0.072 & 0.147 & 0.069 \\
Constant & $(5.8 ; 4.8)$ & $(6.2 ; 5.3)$ & $(11.7 ; 9.1)$ \\
& -.032 & -.041 & -.027 \\
Temporary & $(-6.3 ; 5.3)$ & $(-4.8 ;-4.3)$ & $(-15.2 ;-11.5)$ \\
output $\tilde{y}_{t}$ & 0.122 & 0.120 & 0.112 \\
Temporary & $(2.5 ; 3.3)$ & $(1.4 ; 1.5)$ & $(4.2 ; 4.1)$ \\
outlays $\tilde{g}_{t}$ & -0.875 & -0.830 & -0.900 \\
\hline R-squared & $(-19.6 ;-12.0)$ & $(-10.4 ;-8.0)$ & $(-33.7 ;-13.9)$ \\
\hline
\end{tabular}

Notes: Estimates of equation (16) in the text. Entries are coefficient estimates. Entries in brackets are the ordinary t-statistics and heteroskedasticity-consistent t-statistics, respectively. Regressors are as in Table 7. Col.1 uses Barro's (1986a) GVAR variable for temporary outlays, as updated in Bohn (1998). Col.2 uses the same specification as Table 7, col.1, for a shorter estimation period. Col.3 combined Barro's (1986a) GVAR variable for 1916-95 with the AR(2) estimate from Table 7 for other years. 


\title{
CESifo Working Paper Series
}

\author{
(for full list see www.cesifo.de)
}

1382 Christian Gollier, Optimal Illusions and Decisions under Risk, January 2005

1383 Daniel Mejía and Marc St-Pierre, Unequal Opportunities and Human Capital Formation, January 2005

1384 Luis H. R. Alvarez and Erkki Koskela, Optimal Harvesting under Resource Stock and Price Uncertainty, January 2005

1385 Ruslan Lukach, Peter M. Kort and Joseph Plasmans, Optimal R\&D Investment Strategies with Quantity Competition under the Threat of Superior Entry, January 2005

1386 Alfred Greiner, Uwe Koeller and Willi Semmler, Testing Sustainability of German Fiscal Policy. Evidence for the Period 1960 - 2003, January 2005

1387 Gebhard Kirchgässner and Tobias Schulz, Expected Closeness or Mobilisation: Why Do Voters Go to the Polls? Empirical Results for Switzerland, 1981 - 1999, January 2005

1388 Emanuele Bacchiocchi and Alessandro Missale, Managing Debt Stability, January 2005

1389 Assar Lindbeck and Dirk Niepelt, Improving the SGP: Taxes and Delegation rather than Fines, January 2005

1390 James J. Heckman and Dimitriy V. Masterov, Skill Policies for Scotland, January 2005

1391 Emma Galli \& Fabio Padovano, Sustainability and Determinants of Italian Public Deficits before and after Maastricht, January 2005

1392 Angel de la Fuente and Juan Francisco Jimeno, The Private and Fiscal Returns to Schooling and the Effect of Public Policies on Private Incentives to Invest in Education: A General Framework and Some Results for the EU, January 2005

1393 Juan C. Conesa and Carlos Garriga, Optimal Response to a Demographic Shock, January 2005

1394 Christian Gollier, Optimal Portfolio Management for Individual Pension Plans, February 2005

1395 Ruslan Lukach, Joseph Plasmans and Peter M. Kort, Innovation Strategies in a Competitive Dynamic Setting, February 2005

1396 Gebhard Kirchgässner, (Why) Are Economists Different?, February 2005

1397 Marko Köthenbürger, Panu Poutvaara and Paola Profeta, Why are More Redistributive Social Security Systems Smaller? A Median Voter Approach, February 2005 
1398 Gabrielle Demange, Free Choice of Unfunded Systems: A First Assessment, February 2005

1399 Carlos Fonseca Marinheiro, Sustainability of Portuguese Fiscal Policy in Historical Perspective, February 2005

1400 Roel M. W. J. Beetsma and Koen Vermeylen, The Effect of Monetary Unification on Public Debt and its Real Return, February 2005

1401 Frank Asche, Petter Osmundsen and Maria Sandsmark, Is It All Oil?, February 2005

1402 Giacomo Corneo, Media Capture in a Democracy: The Role of Wealth Concentration, February 2005

1403 A. Lans Bovenberg and Thijs Knaap, Ageing, Funded Pensions and the Dutch Economy, February 2005

1404 Thiess Büttner, The Incentive Effect of Fiscal Equalization Transfers on Tax Policy, February 2005

1405 Luisa Fuster, Ayşe İmrohoroğlu and Selahattin İmrohoroğlu, Personal Security Accounts and Mandatory Annuitization in a Dynastic Framework, February 2005

1406 Peter Claeys, Policy Mix and Debt Sustainability: Evidence from Fiscal Policy Rules, February 2005

1407 James M. Malcomson, Supplier Discretion over Provision: Theory and an Application to Medical Care, February 2005

1408 Thorvaldur Gylfason, Interview with Assar Lindbeck, February 2005

1409 Christian Gollier, Some Aspects of the Economics of Catastrophe Risk Insurance, February 2005

1410 Gebhard Kirchgässner, The Weak Rationality Principle in Economics, February 2005

1411 Carlos José Fonseca Marinheiro, Has the Stability and Growth Pact Stabilised? Evidence from a Panel of 12 European Countries and Some Implications for the Reform of the Pact, February 2005

1412 Petter Osmundsen, Frank Asche, Bård Misund and Klaus Mohn, Valuation of International Oil Companies -The RoACE Era, February 2005

1413 Gil S. Epstein and Shmuel Nitzan, Lobbying and Compromise, February 2005

1414 Marcel F. M. Canoy, Jan C. van Ours and Frederick van der Ploeg, The Economics of Books, February 2005 
1415 Eric A. Hanushek and Ludger Wößmann, Does Educational Tracking Affect Performance and Inequality? Differences-in-Differences Evidence across Countries, February 2005

1416 George Kapetanios and M. Hashem Pesaran, Alternative Approaches to Estimation and Inference in Large Multifactor Panels: Small Sample Results with an Application to Modelling of Asset Returns, February 2005

1417 Samuel Mühlemann, Jürg Schweri, Rainer Winkelmann and Stefan C. Wolter, A Structural Model of Demand for Apprentices. February 2005

1418 Giorgio Brunello and Lorenzo Rocco, Educational Standards in Private and Public Schools, February 2005

1419 Alex Bryson, Lorenzo Cappellari and Claudio Lucifora, Why so Unhappy? The Effects of Unionisation on Job Satisfaction, March 2005

1420 Annalisa Luporini, Relative Performance Evaluation in a Multi-Plant Firm, March 2005

1421 Giorgio Bellettini and Carlotta Berti Ceroni, When the Union Hurts the Workers: A Positive Analysis of Immigration Policy, March 2005

1422 Pieter Gautier, Michael Svarer and Coen Teulings, Marriage and the City, March 2005

1423 Ingrid Ott and Stephen J. Turnovsky, Excludable and Non-Excludable Public Inputs: Consequences for Economic Growth, March 2005

1424 Frederick van der Ploeg, Back to Keynes?, March 2005

1425 Stephane Dees, Filippo di Mauro, M. Hashem Pesaran and L. Vanessa Smith, Exploring the International Linkages of the Euro Area: a Global VAR Analysis, March 2005

1426 Hans Pitlik, Friedrich Schneider and Harald Strotmann, Legislative Malapportionment and the Politicization of Germany's Intergovernmental Transfer System, March 2005

1427 Konstantinos Angelopoulos and Apostolis Philippopoulos, The Role of Government in Anti-Social Redistributive Activities, March 2005

1428 Ansgar Belke and Daniel Gros, Asymmetries in the Trans-Atlantic Monetary Policy Relationship: Does the ECB follow the Fed?, March 2005

1429 Sören Blomquist and Luca Micheletto, Optimal Redistributive Taxation when Government's and Agents' Preferences Differ, March 2005

1430 Olof Åslund and Peter Fredriksson, Ethnic Enclaves and Welfare Cultures - QuasiExperimental Evidence, March 2005

1431 Paul De Grauwe, Roberto Dieci and Marianna Grimaldi, Fundamental and NonFundamental Equilibria in the Foreign Exchange Market. A Behavioural Finance Framework, March 2005 
1432 Peter Egger, Stefan Gruber, Mario Larch and Michael Pfaffermayr, Knowledge-Capital Meets New Economic Geography, March 2005

1433 George Economides and Apostolis Philippopoulos, Should Green Governments Give Priority to Environmental Policies over Growth-Enhancing Policies?, March 2005

1434 George W. Evans and Seppo Honkapohja, An Interview with Thomas J. Sargent, March 2005

1435 Helge Berger and Volker Nitsch, Zooming Out: The Trade Effect of the Euro in Historical Perspective, March 2005

1436 Marc-Andreas Muendler, Rational Information Choice in Financial Market Equilibrium, March 2005

1437 Martin Kolmar and Volker Meier, Intra-Generational Externalities and InterGenerational Transfers, March 2005

1438 M. Hashem Pesaran and Takashi Yamagata, Testing Slope Homogeneity in Large Panels, March 2005

1439 Gjermund Nese and Odd Rune Straume, Industry Concentration and Strategic Trade Policy in Successive Oligopoly, April 2005

1440 Tomer Blumkin and Efraim Sadka, A Case for Taxing Education, April 2005

1441 John Whalley, Globalization and Values, April 2005

1442 Denise L. Mauzerall, Babar Sultan, Namsoug Kim and David F. Bradford, Charging $\mathrm{NO}_{x}$ Emitters for Health Damages: An Exploratory Analysis, April 2005

1443 Britta Hamburg, Mathias Hoffmann and Joachim Keller, Consumption, Wealth and Business Cycles in Germany, April 2005

1444 Kohei Daido and Hideshi Itoh, The Pygmalion Effect: An Agency Model with Reference Dependent Preferences, April 2005

1445 John Whalley, Rationality, Irrationality and Economic Cognition, April 2005

1446 Henning Bohn, The Sustainability of Fiscal Policy in the United States, April 2005 